\section{CrossMark} <click for updates

Cite this: New J. Chem., 2015, 39, 7309

Received (in Victoria, Australia) 30th March 2015.

Accepted 16th July 2015

DOI: 10.1039/c5nj00789e

www.rsc.org/njc

\title{
An enolato-bridged dinuclear Cu(II) complex with a coumarin-assisted precursor: a spectral, magnetic and biological study $\dagger$
}

\author{
Kuheli Das, ${ }^{a}$ Uttam Panda, ${ }^{a}$ Amitabha Datta, ${ }^{\text {b }}$ Suman Roy, ${ }^{a}$ Sudipa Mondal, ${ }^{a}$ \\ Chiara Massera, ${ }^{c}$ Tulin Askun, ${ }^{d}$ Pinar Celikboyun, ${ }^{d}$ Eugenio Garribba, ${ }^{e}$ \\ Chittaranjan Sinha, ${ }^{a}$ Kushi Anand, ${ }^{f}$ Takashiro Akitsu ${ }^{g}$ and Kana Kobayashi ${ }^{9}$
}

\begin{abstract}
A new, phenoxo-bridged $\mathrm{Cu}^{\prime \prime}$ dinuclear complex $\mathrm{Cu}_{2}\left[\left(\mathrm{~L}_{2}(\mathrm{DMF})_{2}\right]\right.$ (1) has been obtained by employing the coumarin-assisted tridentate precursor, $\mathrm{H}_{2} \mathrm{~L}$, [benzoic acid(7-hydroxy-4-methyl-2-oxo-2H-chromen-8ylmethylene)-hydrazide]. Complex 1 has been systematically characterized by FTIR, UV-Vis, fluorescence and EPR spectrometry. The single crystal X-ray diffraction analysis of $\mathbf{1}$ shows that the geometry around each copper ion is square pyramidal, comprising two enolato oxygen atoms belonging to different ligands (which assemble the dimer bridging the two metal centers), one imine- $\mathrm{N}$ and one phenolic- $\mathrm{O}$ atoms of the Schiff base and one oxygen atom from the DMF molecule. The temperature dependent magnetic interpretation agrees with the existence of weak ferromagnetic interactions between the bridging dinuclear $\mathrm{CU}(\mathrm{II})$ ions. Both the ligand and complex 1 exhibit anti-mycobacterial activity and considerable efficacy towards M. tuberculosis H37Rv ATCC 27294 and M. tuberculosis H37Ra ATCC 25177 strains. The cytotoxicity study on human adenocarcinoma cell lines (MCF7) suggests that the ligand and complex 1 have potential anticancer properties. Molecular docking of $\mathrm{H}_{2} \mathrm{~L}$ with the enoyl acyl carrier protein reductase of $M$. tuberculosis $H_{37 R_{v}}$ (PDB ID: $4 \cup 0 K$ ) is examined and the best docked pose of $\mathrm{H}_{2} \mathrm{~L}$ shows one hydrogen bond with Thr196 (1.99 A).
\end{abstract}

\section{Introduction}

Recent research trends reveal that there has been considerable interest among researchers in studying the chemistry of coumarin functionalised compounds due to their broad spectrum of activities ranging from photophysical or photochemical properties $^{1}$ to biological properties. ${ }^{2}$ Many products that contain

\footnotetext{
${ }^{a}$ Department of Chemistry, Inorganic Chemistry Section, Jadavpur University, Kolkata, 700032, India. E-mail: c_r_sinha@yahoo.com; Fax: +91-33-2413-7121

${ }^{b}$ Institute of Chemistry, Academia Sinica, Nankang, Taipei 11529, Taiwan. E-mail: amitd_ju@yahoo.co.in

${ }^{c}$ Dipartimento di Chimica, Università degli Studi di Parma, Viale delle Scienze, 17/A, 43124 Parma, Italy

${ }^{d}$ Department of Biology, Faculty of Sciences and Arts, University of Balikesir, Cagis Campus, 10145, Balikesir, Turkey

${ }^{e}$ Dipartimento di Chimica and Centro Interdisciplinare per lo Sviluppo della Ricerca Biotecnologica e per lo Studio della Biodiversità della Sardegna, Università di Sassari, Via Vienna 2, I-07100 Sassari, Italy

${ }^{f}$ Department of Biochemistry, Indian Institute of Science, Bangalore, 560012, India ${ }^{g}$ Department of Chemistry, Faculty of Science, Tokyo University of Science 1-3 Kagurazaka, Shinjuku-ku, Tokyo 162-8601, Japan

$\dagger$ Electronic supplementary information (ESI) available. CCDC 938644. For ESI and crystallographic data in CIF or other electronic format see DOI: 10.1039/ c5nj00789e
}

a coumarin subunit exhibit diverse biological activities such as molluscicidal $^{3 a}$ and insecticidal activities, ${ }^{3 b}$ cytotoxicity, ${ }^{3 c}$ and anti-HIV activity; ${ }^{3 d}$ some serve as antioxidant ${ }^{3 c}$ and anticoagulant agents. ${ }^{4}$ Basically, the coumarin nucleus is one of the most interesting chromophores with high fluorescence efficiency, ${ }^{5}$ which opens up a new way for recognition and determination of metal cations or anions. ${ }^{6}$ There are several coumarin appended fluorescent sensors reported in the literature which are potentially used to detect cations e.g. $\mathrm{Ca}^{2+}, 6 a \mathrm{Zn}^{2+}, 6 b$ and $\mathrm{Cu}^{2+6 c}$ as well as anions e.g. fluorides, ${ }^{6 d}$ cyanides, etc. It is well established that the biological activity associated with hydrazone compounds is attributed to the presence of the active pharmacophore $(-\mathrm{CONH}-\mathrm{N}=\mathrm{C}-),{ }^{7}$ and many hydrazone compounds containing this active moiety showed good anticancer, antituberculosis and antibacterial activities. ${ }^{8}$ Additionally, the azomethine (-CONH-N=C-) group in hydrazone derivatives possesses strong binding ability due to the formation of stable chelates with metal ions. So, coumarin containing hydrazone derivatives are not only expected to have enhanced biological activities but also show high sensitivity towards metal ions. Indeed, chelation studies involving metal ions coordinated to coumarin derivatives at different positions have been reported in the literature. ${ }^{9}$ 8-Substituted-4-methyl-7-hydroxycoumarin 
and 6-substituted-4-methyl-7-hydroxycoumarin have been investigated due to their complexation ability and exhibited anticoagulant and plant growth regulating properties. ${ }^{10}$ Some of us previously reported one $\mathrm{Cu}(\mathrm{II})$ derivative mediated by $\mathrm{N}$-[(2-pyridyl)methyliden]-6-coumarin. ${ }^{11}$

Dinuclear transition metal complexes have gained significant interest over the years due to their diverse properties and reactivity, originating from the magnetic exchange occurring between neighbouring metal centres and potential applications in the field of magnetism ${ }^{12}$ and biochemistry. ${ }^{13}$ So far, several copper ions coordinated to oxygen and/or nitrogen atoms as structural and functional models in magneto-chemistry and metalloenzymes have been reported in the literature. ${ }^{14}$ Copper is the third most abundant transition metal found in living systems, ${ }^{15}$ and it plays an essential role in biological systems. The nature (antiferromagnetic or ferromagnetic) and magnitude of a magnetic exchange interaction between two metal ions are reasonably well understood in terms of the energetics and overlap of 'magnetic' orbitals. ${ }^{16}$ In the last few years, the success in understanding magnetic exchange interactions in metal complexes has prompted efforts to see if these complexes can be used as molecular building blocks for materials exhibiting interesting properties. The magnetic spin exchange in dinuclear copper(II) complexes in relation to the participation of donor atoms of the corresponding ligand is of continuing interest. ${ }^{17}$ The design of ligands capable of binding two metal ions in close proximity is, therefore, an important subject in this field. In order to gain an insight into the correlation between the structure and magnetism of dinuclear copper(II) complexes, detailed investigations based on crystal structure analyses are needed. Tuberculosis, which is caused primarily by Mycobacterium tuberculosis and rarely by $M$. bovis and $M$. africanum, is one of the oldest disease in the world affecting lungs and spreading to the other organs. ${ }^{18}$ At present, a million children per year have died from this disease. ${ }^{19}$ Mycobacteria resist to many chemicals, disinfectant antibiotics and chemotherapeutical agents. ${ }^{20}$ Mycobacteria show a strong resistance to most of the antibiotics and chemicals due to the low permeability of the mycobacterial cell wall. Porins of the thickness and low permeability of this bilayer membrane allow inefficient permeability of the substances. ${ }^{20 b}$ The prospect of developing new and effective drugs is central to the global control of tuberculosis.

In the present contribution, the ligand [benzoic acid(7hydroxy-4-methyl-2-oxo-2 $H$-chromen-8-ylmethylene)-hydrazide] $\left(\mathrm{H}_{2} \mathrm{~L}\right)$, a tridentate ONO donor, ${ }^{21}$ was used in order to synthesize the $\mathrm{Cu}(\mathrm{II})$ dinuclear complex $\mathrm{Cu}_{2}\left[(\mathrm{~L})_{2}(\mathrm{DMF})_{2}\right](\mathbf{1})$. Besides studying the systematic spectral and magnetic properties, we have focused our attention on the anti-mycobacterial activity of human tuberculosis cells like M. tuberculosis H37Rv ATCC 27294 and M. tuberculosis H37Ra ATCC 25177 strains. We also have examined the cytotoxicity study on human adenocarcinoma cell lines (MCF7). The anti-microbacterial efficiency of $\mathrm{H}_{2} \mathrm{~L}$ is examined by molecular docking with the enoyl acyl carrier protein reductase of $M$. tuberculosis $\mathrm{H}_{37 \mathrm{R}_{\mathrm{v}}}(\mathrm{PDB}$ ID: 4U0K).

\section{Experimental}

\section{Materials}

All chemicals and solvents were of reagent grade and used as received. $\mathrm{Cu}\left(\mathrm{NO}_{3}\right)_{2} \cdot 3 \mathrm{H}_{2} \mathrm{O}$ was purchased from Merck, India. Benzohydrazide and 7-hydroxy-4-methyl-coumarin were purchased from Aldrich Chemicals, India.

\section{Physical measurements}

Microanalytical data (C, H, and N) were collected on a Perkin-Elmer $2400 \mathrm{CHNS} / \mathrm{O}$ elemental analyzer. FTIR spectra were recorded on a Perkin-Elmer RX-1 spectrophotometer in the range $4000-400 \mathrm{~cm}^{-1}$ as $\mathrm{KBr}$ pellets. Electronic spectra were measured on a Lambda 25 (UV-vis-NIR) spectrophotometer. Emission spectra were recorded using an LS 55 Perkin-Elmer spectrofluorometer at room temperature $(298 \mathrm{~K})$ in different solutions under degassed conditions. The fluorescence quantum yield of the complexes was determined using carbazole as a reference with a known $\phi_{\mathrm{R}}$ of 0.42 in benzene. ${ }^{22}$ The complex and the reference dye were excited at the same wavelength, maintaining a nearly equal absorbance $(\sim 0.1)$, and the emission spectra were recorded. The area of the emission spectrum was integrated using the software available in the instrument and the quantum yield was calculated according to the following equation:

$$
\frac{\phi_{\mathrm{S}}}{\phi_{\mathrm{R}}}=\left[\frac{A_{\mathrm{S}}}{A_{\mathrm{R}}}\right] \times\left[\frac{(\mathrm{Abs})_{\mathrm{R}}}{(\mathrm{Abs})_{\mathrm{S}}}\right] \times\left[\frac{\eta_{\mathrm{S}}^{2}}{\eta_{\mathrm{R}}^{2}}\right]
$$

here, $\phi_{\mathrm{S}}$ and $\phi_{\mathrm{R}}$ are the fluorescence quantum yield of the sample and the reference, respectively. $A_{\mathrm{S}}$ and $A_{\mathrm{R}}$ are the area under the fluorescence spectra of the sample and the reference, respectively, $(\mathrm{Abs})_{\mathrm{S}}$ and $(\mathrm{Abs})_{\mathrm{R}}$ are the respective optical densities of the sample and the reference solution at the wavelength of excitation, and $\eta_{\mathrm{S}}$ and $\eta_{\mathrm{R}}$ are the values of the refractive index of the respective solvent used for the sample and the reference. Fluorescence lifetimes were measured using a time-resolved spectrofluorometer from IBH, UK. The instrument uses a picosecond diode laser (NanoLed-03, $370 \mathrm{~nm}$ ) as the excitation source and works on the principle of time-correlated single photon counting. ${ }^{23}$ The goodness of fit was evaluated by the $\chi^{2}$ criterion and the visual inspection of the residuals of the fitted function to the data. EPR spectra were recorded from 0 to 10000 Gauss in the temperature range 77-298 $\mathrm{K}$ using an X-band (9.4 GHz) Bruker EMX spectrometer. EPR parameters reported in the text were obtained by simulating the spectra using the computer program Bruker WinEPR SimFonia. ${ }^{24}$ Electronic absorption spectra were recorded using a Perkin-Elmer Lambda 35 spectrophotometer. Magnetic properties were investigated using a Quantum Design MPMS-XL superconducting quantum interference device magnetometer (SQUID) at an applied field $0.5 \mathrm{~T}$ in a temperature range 5-300 $\mathrm{K}$. The diamagnetic correction was carried out by using Pascal constants.

\section{Synthesis of the ligand and the complex}

Synthesis of the ligand $\left(\mathrm{H}_{2} \mathrm{~L}\right)$. 8-Formyl-7-hydroxy-4-methylcoumarin was prepared from 7-hydroxy-4-methyl-coumarin using the reported procedure. ${ }^{25}$ Ligand $\mathrm{H}_{2} \mathrm{~L}$ was synthesized by 
Table 1 Crystallographic data of 1

\begin{tabular}{ll}
\hline Empirical formula & $\mathrm{C}_{42} \mathrm{H}_{38} \mathrm{Cu}_{2} \mathrm{~N}_{6} \mathrm{O}_{10}$ \\
\hline Formula weight & 913.86 \\
Temperature & $293(2)$ \\
Wavelength $(\AA)$ & 0.71069 \\
Crystal system & Monoclinic \\
Space group & $P 21 / n$ \\
$a(\AA)$ & $8.2580(10)$ \\
$b(\AA)$ & $11.221(2)$ \\
$c(\AA)$ & $21.508(3)$ \\
$\beta($ deg$)$ & $97.190(2)$ \\
Volume $\left(\AA^{3}\right)$ & $1977.3(5)$ \\
$Z$ & 2 \\
$D_{\text {calc }}\left(\mathrm{mg}\right.$ m $\left.{ }^{-3}\right)$ & 1.535 \\
$\mu($ MoK $\alpha)\left(\mathrm{mm}{ }^{-1}\right)$ & 1.144 \\
$F(000)$ & 940 \\
Crystal size, mm & -3 \\
$\theta$ range for data collection & $0.15 \times 0.12 \times 0.09$ \\
Reflections collected/unique & $1.91-30.63$ \\
Observed reflections $\left[F_{\mathrm{o}}>4 \sigma\left(F_{\mathrm{o}}\right)\right]$ & $31462 / 6071[R(\mathrm{int})=0.0358]$ \\
Data/restraints/parameters & 4850 \\
Final $R$ indices $\left[F_{\mathrm{o}}>4 \sigma\left(F_{\mathrm{o}}\right)\right]^{b}$ & $6071 / 0 / 314$ \\
$R$ indices (all data) & $R_{1}=0.0358, \mathrm{w} R_{2}=0.0963$ \\
Goodness-of-fit on $F^{2 a}$ & $R_{1}=0.0483, \mathrm{w} R_{2}=0.1040$ \\
Largest diff. peak and hole, e $\AA^{-3}$ & 1.046 \\
$a$ Goodness-of-fit $S=\left[\sum \mathrm{w}\left(F_{\mathrm{o}}{ }^{2}-F_{\mathrm{c}}{ }^{2}\right)^{2} /(n-p)\right] 1 / 2$, where $n$ is the number \\
of reflections and $p$ is the number of parameters. ${ }^{b} R_{1}=\sum\left\|F_{\mathrm{o}}|-| F_{\mathrm{c}}\right\| /$ \\
$\sum\left|F_{\mathrm{o}}\right| ;$ w $R_{2}=\left[\sum\left[\mathrm{w}\left(F_{\mathrm{o}}{ }^{2}-F_{\mathrm{c}}{ }^{2}\right)^{2}\right] / \sum\left[\mathrm{w}\left(F_{\mathrm{o}}{ }^{2}\right)^{2}\right]\right]^{1 / 2}$. \\
\hline
\end{tabular}

refluxing 8-formyl-7-hydroxy-4-methyl-coumarin (0.408 g, 2 mmol) and benzohydrazide $(0.272 \mathrm{~g}, 2 \mathrm{mmol})$ for a period of $2 \mathrm{~h}$ in methanol to obtain the yellow colored compound. It was filtered, washed with excess of methanol and recrystallized from dioxane (see Scheme ESI $\dagger$ ). Yield: $0.231 \mathrm{~g}(72 \%)$. Anal. calc. for $\mathrm{C}_{18} \mathrm{H}_{14} \mathrm{~N}_{2} \mathrm{O}_{4}$ : C, 66.72; H, 4.91; N, 8.45. Found: C, 67.07; H, 4.38; N, 8.69\%. ${ }^{1} \mathrm{H}$ NMR (300 MHz, $\left.\mathrm{CDCl}_{3}\right): \delta 2.4\left(\mathrm{~s}, 3 \mathrm{H}, \mathrm{C} 18-\mathrm{CH}_{3}\right), 6.25(\mathrm{~s}, 1 \mathrm{H}$, C3-H), 6.96-6.99 (d, 1H, C6-H, J = 9 Hz), 7.53-7.63 (m, 3H, C-14, C-15, C-16), 7.71-7.74 (d, 1H, C5-H, J = $9 \mathrm{~Hz}$ ), 7.98-7.96 (d, 2H, $\mathrm{C}-13, \mathrm{C}-17, J=6.9 \mathrm{~Hz}), 8.70(\mathrm{~s}, 1 \mathrm{H}, \mathrm{HC}=\mathrm{N}), 12.44(\mathrm{~s}, 1 \mathrm{H}, \mathrm{NH})$, 12.87 (s, 1H, OH).

Synthesis of $\mathrm{Cu}_{2}\left[(\mathrm{~L})_{2}(\mathrm{DMF})_{2}\right]$ (1). To a methanol solution $(10 \mathrm{~mL})$ of $\mathrm{Cu}\left(\mathrm{NO}_{3}\right)_{2} \cdot 3 \mathrm{H}_{2} \mathrm{O}(0.482 \mathrm{~g}, 2 \mathrm{mmol})$, the ligand $\mathrm{H}_{2} \mathrm{~L}$ $(0.644 \mathrm{~g}, 2 \mathrm{mmol})$ in $15 \mathrm{~mL}$ of DMF was added upon constant stirring. The resulting green solution was kept undisturbed at room temperature. Dark-green square-shaped single crystals of 1 were generated after one week. These were separated by filtration and air-dried before X-ray diffraction analysis. Yield: 0.69 g. Anal. calc. for $\mathrm{C}_{42} \mathrm{H}_{38} \mathrm{Cu}_{2} \mathrm{~N}_{6} \mathrm{O}_{10}: \mathrm{C}, 55.20 ; \mathrm{H}, 4.20 ; \mathrm{N}$, 9.19. Found: C, 55.373; H, 3.87; N, 9.58\%.

\section{X-ray crystallography}

The crystal structure of $\mathbf{1}$ was determined by X-ray diffraction methods. Crystal data and experimental details of data collection and structure refinement are reported in Table 1 . Intensity data and cell parameters were recorded at 293(2) K on a Bruker Breeze (MoK $\alpha$ radiation $\lambda=0.71069 \AA$ ) equipped with a CCD area detector and a graphite monochromator. The $\omega: 2 \theta$ scan technique was applied within a $\theta$ range of $1.91-30.63^{\circ}$. No significant crystal decay was observed. A total of 31462 reflections were collected of which 4850 were independent $[R($ int $)=0.0358]$ reflections.
The raw frame data were processed using SAINT and SADABS to yield the reflection data file. ${ }^{26}$ The structure was solved by Direct Methods using the SIR97 program ${ }^{27}$ and refined on $F_{\mathrm{o}}{ }^{2}$ by full-matrix least-squares procedures, using the SHELXL-97 program $^{28}$ in the WinGX suite v.1.80.05. ${ }^{29}$ All non-hydrogen atoms were refined by anisotropic atomic displacements. The hydrogen atoms were included in the refinement at idealized geometry (C-H $0.95 \AA$ A) and refined "riding" on the corresponding parent atoms. The weighting scheme used in the last cycle of refinement was $\mathrm{w}=1 /\left[\sigma^{2} F_{\mathrm{o}}{ }^{2}+(0.0583 P)^{2}+0.4073 P\right]$, where $P=\left(F_{\mathrm{o}}{ }^{2}+2 F_{\mathrm{c}}{ }^{2}\right) / 3$. CCDC-938644 for 1 .

\section{Theoretical calculation}

Full geometry optimization of $\mathbf{1}$ was carried out using density functional theory (DFT) at the B3LYP level. ${ }^{30}$ All calculations were performed using the Gaussian 03 program package ${ }^{31}$ with the aid of the Gauss View visualization program. ${ }^{32}$ For $\mathrm{C}, \mathrm{H}, \mathrm{N}, \mathrm{O}$, and $\mathrm{Cl}$ the $6-31 \mathrm{G}(\mathrm{d})$ basis set was assigned, while for $\mathrm{Cu}$ and $\mathrm{Ni}$ the LanL2DZ basis set with effective core potential was employed. ${ }^{33}$ The vibrational frequency calculations were performed to ensure that the optimized geometries represent the local minima and there are only positive eigen values. Vertical electronic excitations based on B3LYP optimized geometries were computed by the time-dependent density functional theory (TD-DFT) formalism $^{34-36}$ in acetonitrile using the conductor-like polarizable continuum model (CPCM). ${ }^{37}$ The Gauss sum was used to calculate the fractional contributions of various groups to each molecular orbital. ${ }^{38}$

\section{Anti-mycobacterial activity}

Medium. In the assays, Mycobacteria Growth Indicator Tubes (MGITs) and their supplements, BBL MGIT OADC enrichment and BBL MGIT PANTA were purchased from BD. The MGIT (Mycobacteria Growth Indicator Tube) contains $4 \mathrm{~mL}$ of modified Middlebrook 7H9 Broth base.

Inoculum preparation. For the cultivation of mycobacteria, the MGIT (Mycobacteria Growth Indicator Tube), a fluorescent compound, is embedded in silicone at the bottom, and then $4 \mathrm{~mL}$ of modified Middle brook 7H9 Broth base are added to the mixture. After that $0.5 \mathrm{~mL}$ of OADC (oleic acid, albumin, dextrose and catalase) enrichment, and the PANTA antibiotic mixture used to prevent the growth of any non-mycobacteria $(0.1 \mathrm{~mL})$ are added to this medium. Oleic acid plays an important role in the metabolism of mycobacteria; albumin acts as a protective agent; dextrose is an energy source; catalase destroys toxic peroxides. Tubes are incubated at $37{ }^{\circ} \mathrm{C}$. For positive control, MGIT tubes are prepared by inoculating bacteria. An un-inoculated MGIT tube is used as a negative control. Blood agar is used for checking the growth of other bacteria. Daily tube reading starts on the second day of incubation using a Micro MGIT fluorescence reader which has long wave UV light. ${ }^{39}$ To prepare inoculums from a positive BACTEC MGIT tube, the positive tubes (day 1 or day 2 positive) are used directly as inoculums. The positive tubes between day 3 and day 5 are diluted to $1: 4$ ratio using sterile saline. Inoculums, prepared from a Day 1 to Day 5 MGIT $7 \mathrm{~mL}$ positive tube, range between 
$0.8 \times 10^{5}$ and $3.2 \times 10^{5} \mathrm{CFU} \mathrm{mL}^{-1}$. Each assay is performed according to the MGIT manual fluorometric susceptibility test procedure recommended by the manufacturer. ${ }^{39,40}$

Antimycobacterial susceptibility assay. The activity of the ligand, $\mathrm{H}_{2} \mathrm{~L}$, and complex 1 against $M$. tuberculosis strains was tested using the Microplate Presto Blue Assay (MPBA) by the method described by Collins \& Franzblau ${ }^{41}$ and modified by Jimenez-Arellanes et al. ${ }^{42} 128 \mu \mathrm{L}$ of compound 1 and $72 \mu \mathrm{L}$ of $7 \mathrm{H} 9$ broth were transferred into the first column, and then $100 \mu \mathrm{L}$ of 7H9 broth was transferred from column 2 to column 8. Column 9 and 10 were the positive and the negative control, respectively. $100 \mu \mathrm{L}$ of a mixture of broth and the compound were transferred from column 1 to column 2 and then mixed using pipettes three times; the procedure was repeated to provide serial 1:2 dilutions. $100 \mu \mathrm{L}$ of the excess medium was discarded from the wells in column 8. Afterwards, $20 \mu \mathrm{L}$ of $M$. tuberculosis inoculum was added to the wells of column 1 to 8 and to the positive control columns. Negative control columns were not inoculated with bacteria. Positive control columns included 7H9 broth and bacteria, while negative control columns contained 7H9 broth and compound 1. Final-test concentration ranges were 423.68$6.62 \mu \mathrm{mol} \mathrm{L}^{-1}$ in the mixture. Microplates were inoculated with the bacterial suspension $(20 \mu \mathrm{L}$ per well) except for the negative control and incubated at $37^{\circ} \mathrm{C}$ for 6 days. Presto blue $(15 \mu \mathrm{L}$, Life Technologies) was then added to the bacterial growth control wells (without compound 1) and the microplates were incubated at $37^{\circ} \mathrm{C}$ for an additional $24 \mathrm{~h}$. If the dye turned from blue to pink (indicating positive bacterial growth), the Presto blue solution was added to the other wells to determine the MIC values. All tests were performed in triplicate. The minimal inhibitory concentration (MIC) was defined as the lowest concentration of the sample that prevents a color change to pink. The minimal bactericidal concentration (MBC) corresponded to the minimum compound concentration which does not cause a color change in the cultures when re-incubated in fresh medium. ${ }^{43}$ Streptomycin (STR) from Sigma and isoniazid (INH) from Fluka were used as standard drugs.

\section{Cytotoxicity assay}

Cell lines and culture conditions. MCF7, a human breast adenocarcinoma cell line, was obtained from the American Type Culture Collection (ATCC, Bethesda, MD, USA). Cells were grown in DMEM (Invitrogen, USA) containing 10\% heat inactivated fetal bovine serum (FBS) (GIBCO BRL, USA), at $37{ }^{\circ} \mathrm{C}$ in a humidified atmosphere containing $5 \% \mathrm{CO}_{2}$.

Cell viability test by MTT assay. MTT [3-(4,5-dimethylthiazol2-yl)-2,5-diphenyl tetrazolium bromide] assay was performed to determine the effect of compound 1 and the ligand $(0.4,0.8$, $1.6,3.12,6.25,12.50,25,50$, and $100 \mu \mathrm{M})$ on the proliferation of MCF7 cells by their utilization and conversion to formazan according to the method of Mosmann. ${ }^{44}$ MCF7 cells were plated into 96-well microtiter plates at a density of $2.5 \times 10^{4}$ cells per well. After $24 \mathrm{~h}$, the culture medium was replaced by $200 \mu \mathrm{L}$ (0-100 $\mu \mathrm{M})$ of compound, and the cells were incubated for 24 and 48 h. DMSO treated cells were used as controls. After treatment, the media were replaced with serum free DMEM media containing $1 \mathrm{mg} \mathrm{mL}{ }^{-1}$ of MTT and incubated at $37{ }^{\circ} \mathrm{C}$ in a $5 \% \mathrm{CO}_{2}$ incubator for additional $5 \mathrm{~h}$. After $5 \mathrm{~h}$, the unreacted dye was removed, and the insoluble formazan crystals were dissolved in $100 \mu \mathrm{L}$ per well DMSO and measured spectrophotometrically in a VersaMax tunable microplate reader (Molecular Devices, Sunnyvale, CA, USA) at $570 \mathrm{~nm}$. The relative cell viability (\%) related to control wells containing cell culture medium without samples was calculated by $A_{570 \mathrm{~nm}}[\mathrm{sample}] /$ $A_{570 \mathrm{~nm}}[$ control $] \times 100$.

\section{Docking studies}

Molecular docking is used to predict how a protein interacts with small molecules. The crystal structure of enoyl acyl carrier protein reductase of $M$. tuberculosis $\mathrm{H}_{37 \mathrm{R}}$ was downloaded from the RCSB protein data bank (http://www.pdb.org) and used for docking. The protein (PDB id: 4U0K) was co-crystallized with (3S)- $N$-(5-chloro-2-methylphenyl)-1-cyclohexyl-5-oxopyrrolidine-3carboxamide and nicotinamide-adenine-dinucleotide. In silico docking studies were performed using the CDOCKER module of the Receptor-Ligand interaction protocol section of Discovery Studio client 3.5. ${ }^{45}$ Initially, there was a pretreatment process for the protein and the ligand. The structure of the ligand was drawn using Chemdraw 5.0, saved in .mol file and finally the .mol file was imported to the Discovery studio 4.0 platform. Ligand preparation was done using the Prepare Ligand module in the Receptor-Ligand interaction tool of Discovery studio 4.0 and the prepared ligand was used for docking. Protein preparation was done under the Prepare Protein module of the ReceptorLigand interaction tool of Discovery Studio 4.0 and that was used for docking. Then we have defined the protein as the total receptor and the active site was selected based on the ligand binding domain of (3S)- $N$-(5-chloro-2-methylphenyl)-1-cyclohexyl5-oxopyrrolidine-3-carboxamide and nicotinamide-adeninedinucleotide. Then the pre-existing ligand was removed and the prepared ligand was placed. The most favorable docked pose was selected according to the minimum free energy of the protein-ligand complex and analyzed to investigate the interaction.

\section{ADMET prediction}

Absorption, distribution, metabolism, excretion and toxicity (ADMET) predictions were done in the ADMET descriptor module of the Small molecule protocol of Discovery studio client 4.0. The druglikeness of the compounds was also checked following Lipinski's rule of five. ${ }^{46,47}$

\section{Results and discussion}

\section{Synthesis and formulation}

The ligand, [benzoic acid(7-hydroxy-4-methyl-2-oxo-2H-chromen-8yl-methylene)-hydrazide] $\left(\mathrm{H}_{2} \mathrm{~L}\right)$, was prepared by the condensation of 8-formyl-7-hydroxy-4-methyl-coumarin with benzohydrazide (1:1 mole proportion) in methanol. $\mathrm{H}_{2} \mathrm{~L}$ was then reacted with $\mathrm{Cu}\left(\mathrm{NO}_{3}\right)_{2} \cdot 3 \mathrm{H}_{2} \mathrm{O}$ in methanol to yield the complex $\mathrm{Cu}_{2}\left[(\mathrm{~L})_{2}(\mathrm{DMF})_{2}\right]$ (1), which was crystallized by slow evaporation of the solvent. 


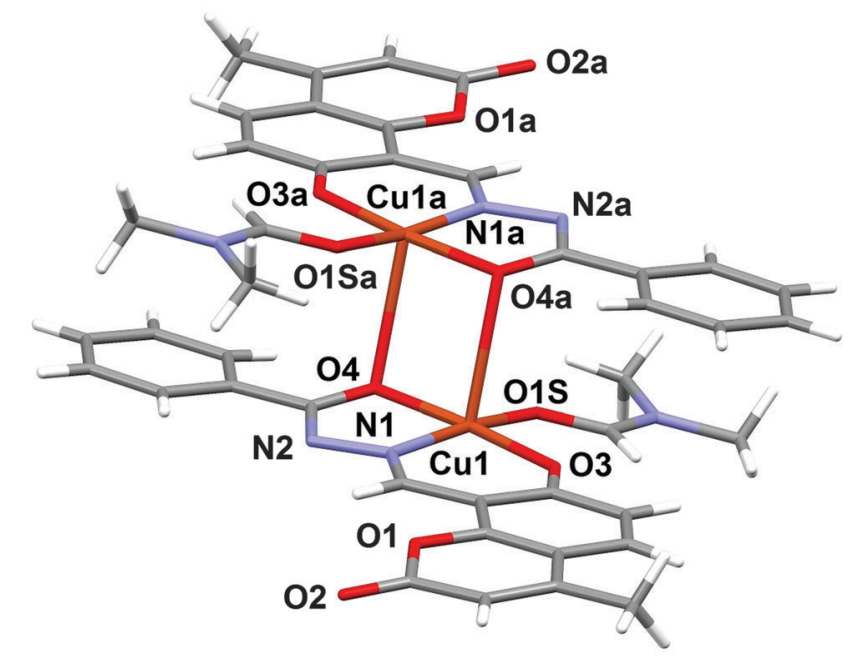

Fig. 1 Molecular structure of complex 1 with the partial labeling scheme.

The IR spectra of 1 show a $\nu(\mathrm{O}=\mathrm{C}-\mathrm{O})$ band at $1720 \mathrm{~cm}^{-1}$ that represents the stretching frequency of the lactone (the corresponding peak appears at $1707 \mathrm{~cm}^{-1}$ in $\mathrm{H}_{2} \mathrm{~L}$ ). The band at $1618 \mathrm{~cm}^{-1}$ is assigned to coordinated $\nu(\mathrm{C}=\mathrm{N}),{ }^{48}$ whereas in the free ligand, the band appears at a lower wavenumber $\left(1613 \mathrm{~cm}^{-1}\right)$. A high intensity band in the region $1303-1269 \mathrm{~cm}^{-1}$ is assigned to the phenolic $\nu(\mathrm{C}-\mathrm{O})$ vibration, whereas the shifting of this band at 1370-1400 $\mathrm{cm}^{-1}$ supports the coordination of the phenolic oxygen to the metal ion via deprotonation. The $\nu_{(\mathrm{M}-\mathrm{N})}$ and $\nu_{(\mathrm{M}-\mathrm{O})}$ stretching frequencies are observed at 712 and $462 \mathrm{~cm}^{-1}$.

\section{Crystal structure}

The molecular structure of the dinuclear copper compound is shown in Fig. 1. Relevant bond lengths and angles are given in Table 2. The geometric centre of the molecule lies on a crystallographic inversion centre. The geometry of the $\mathrm{NO}_{4}$ environment around each copper ion is square pyramidal, as evidenced by the $\tau$ value ${ }^{49}$ of 0.08 . The dimer is assembled via the $\mu_{2}$-enolato oxygen atoms $\mathrm{O} 4$ and its centrosymmetric analogue $\mathrm{O} 4 \mathrm{a}$, belonging to two distinct deprotonated ligand $\mathrm{L}^{2-}$. Each of the oxygen atoms bridge two adjacent copper ions, thus occupying both the apical position of the pyramid around one metal center, and the equatorial position of its centrosymmetric counterpart. The coordination around copper is completed by the imine-N(1) and phenolic-O(3) atoms of the Schiff base and by the O1S atom of the DMF molecule. This arrangement gives rise to a $\mathrm{Cu}_{2} \mathrm{O}_{2}$ distorted square and to a pair of five and six-membered chelate rings. The Cu1-Cu1a distance is 3.429(6) $\AA$, which is in good

Table 2 Selected bond lengths $[\AA ̊]$ and angles $\left[{ }^{\circ}\right]$ for 1

\begin{tabular}{|c|c|c|c|}
\hline $\mathrm{Cu} 1-\mathrm{O} 3$ & $1.892(1)$ & $\mathrm{O} 4-\mathrm{Cu} 1-\mathrm{O} 3$ & $174.34(5)$ \\
\hline $\mathrm{Cu} 1-\mathrm{O} 4$ & $1.943(1)$ & $\mathrm{O} 3-\mathrm{Cu} 1-\mathrm{N} 1$ & $93.08(5)$ \\
\hline $\mathrm{Cu} 1-\mathrm{O} 4^{a}$ & 2.651(1) & O3-Cu1-O1S & $93.12(5)$ \\
\hline Cu1-N1 & 1.919(1) & $\mathrm{O} 4-\mathrm{Cu} 1-\mathrm{O} 1 \mathrm{~S}$ & $92.03(5)$ \\
\hline Cu1-O1S & 1.971(1) & $\mathrm{N} 1-\mathrm{Cu} 1-\mathrm{O} 4$ & $81.42(5)$ \\
\hline & & N1-Cu1-O1S & $167.52(5)$ \\
\hline
\end{tabular}

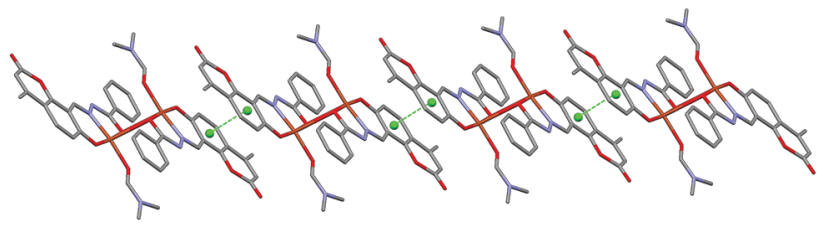

Fig. $2 \pi-\pi$ stacking interactions present in the crystal structure of $\mathbf{1}$, shown along the $b$ axis of the unit cell. Centroids are represented as green spheres.

agreement with previously reported doubly phenolato-bridged copper complexes, ${ }^{50,51}$ where the $\mathrm{Cu}-\mathrm{Cu}$ separation is in the range 2.901-3.345 $\AA$. The Cu1-O4 distance is 1.943(1) $\AA$, which is comparable with similar bond distances [1.922(4) and 1.941(4) ̊] reported in the literature. ${ }^{50 a}$ On the other hand, the Cu1-O4Cu1a angle of $95.33(4)^{\circ}$ is relatively small if compared with literature data, ${ }^{50 a, d, 52}$ where the angular values span from 95.7 to $107.5^{\circ} .^{53}$ In the lattice, the crystal structure is stabilized by weak $\pi-\pi$ stacking interactions involving the aromatic rings of the ligand. Fig. 2 shows the packing along the $b$ axis of the unit cell, with centroid . . centroid distances of 3.849(5) A.

\section{Electronic spectra}

The electronic spectra for $\mathrm{H}_{2} \mathrm{~L}$ and complex 1 were recorded in HPLC grade dimethyl formamide and methanol, respectively. For $\mathrm{H}_{2} \mathrm{~L}$, the absorption bands at $314\left(\varepsilon=201600 \mathrm{M}^{-1} \mathrm{~cm}^{-1}\right)$, $347\left(\varepsilon=115818 \mathrm{M}^{-1} \mathrm{~cm}^{-1}\right), 383\left(\varepsilon=38218 \mathrm{M}^{-1} \mathrm{~cm}^{-1}\right)$ and $463 \mathrm{~nm}\left(\varepsilon=28072 \mathrm{M}^{-1} \mathrm{~cm}^{-1}\right)$ are attributed to $\pi \rightarrow \pi^{*}$ and $n \rightarrow \pi^{*}$ transitions. ${ }^{54}$ Upon complexation, the $\pi \rightarrow \pi^{*}$ band shifts from 314 to $337 \mathrm{~nm}\left(\varepsilon=38750 \mathrm{M}^{-1} \mathrm{~cm}^{-1}\right)$, while the $n \rightarrow \pi^{*}$ band moves to $392\left(\varepsilon=21583 \mathrm{M}^{-1} \mathrm{~cm}^{-1}\right)$ and $408 \mathrm{~nm}\left(\varepsilon=20541 \mathrm{M}^{-1} \mathrm{~cm}^{-1}\right)$. Furthermore for the complex, a pure $\mathrm{d}-\mathrm{d}$ transition appears at $650 \mathrm{~nm}\left(\varepsilon=1008 \mathrm{M}^{-1} \mathrm{~cm}^{-1}\right){ }^{55}$

The spectral characteristics are explained with the help of a DFT computation of the optimized structure of $\mathbf{1}$. The orbital energies along with the contributions to some MOs from the ligands and the metal for a few MOs are given in Fig. 3, while the orbital energies of the ligands and the complex are given in Table S1 (ESI $\dagger$ ). As complex 1 contains two unpaired electrons as $s=1 / 2$, it shows two spin states designated as $\alpha$ and $\beta$. Both filled and vacant $\alpha$-MOs from HOMO -5 to LUMO +5 constitute mainly of ligand orbitals $\left(\mathrm{L}^{2-}\right)$. The metal and DMF contributions are insignificant in both filled and vacant MOs; only HOMO-5 and HOMO-4 carry $15 \%$ and $14 \% \mathrm{Cu}$ functions whereas LUMO+4 and LUMO+5 carry 9\% and 12\% DMF functions in the $\alpha$ state, respectively. Thus, the ligand $\mathrm{L}^{2-}$ controls the molecular functions and hence the electronic properties of the complexes. Thus, in the $\alpha$ state all the transition bands are basically considered as ILCT in nature. The intensity of these transitions has been assessed by the oscillator strength $(f)$. $\mathrm{HOMO} \rightarrow$ LUMO is considered as $\mathrm{L}(\pi) \rightarrow \mathrm{L}\left(\pi^{*}\right)$ with $f=0.5762$ at $405.8 \mathrm{~nm}$; HOMO-1 $\rightarrow$ LUMO+3 is found at $335.3 \mathrm{~nm}$ with $f=0.3549$ which is also represented as ILCT (see Table S2, ESI $\dagger$ ). In a similar way, the orbital energy of the $\beta$ state of $\mathbf{1}$ was also calculated (see Table S3, ESI $\dagger$ ) and the calculated transitions are grouped. Here also the contribution of the ligand $\mathrm{L}^{2-}$ in 


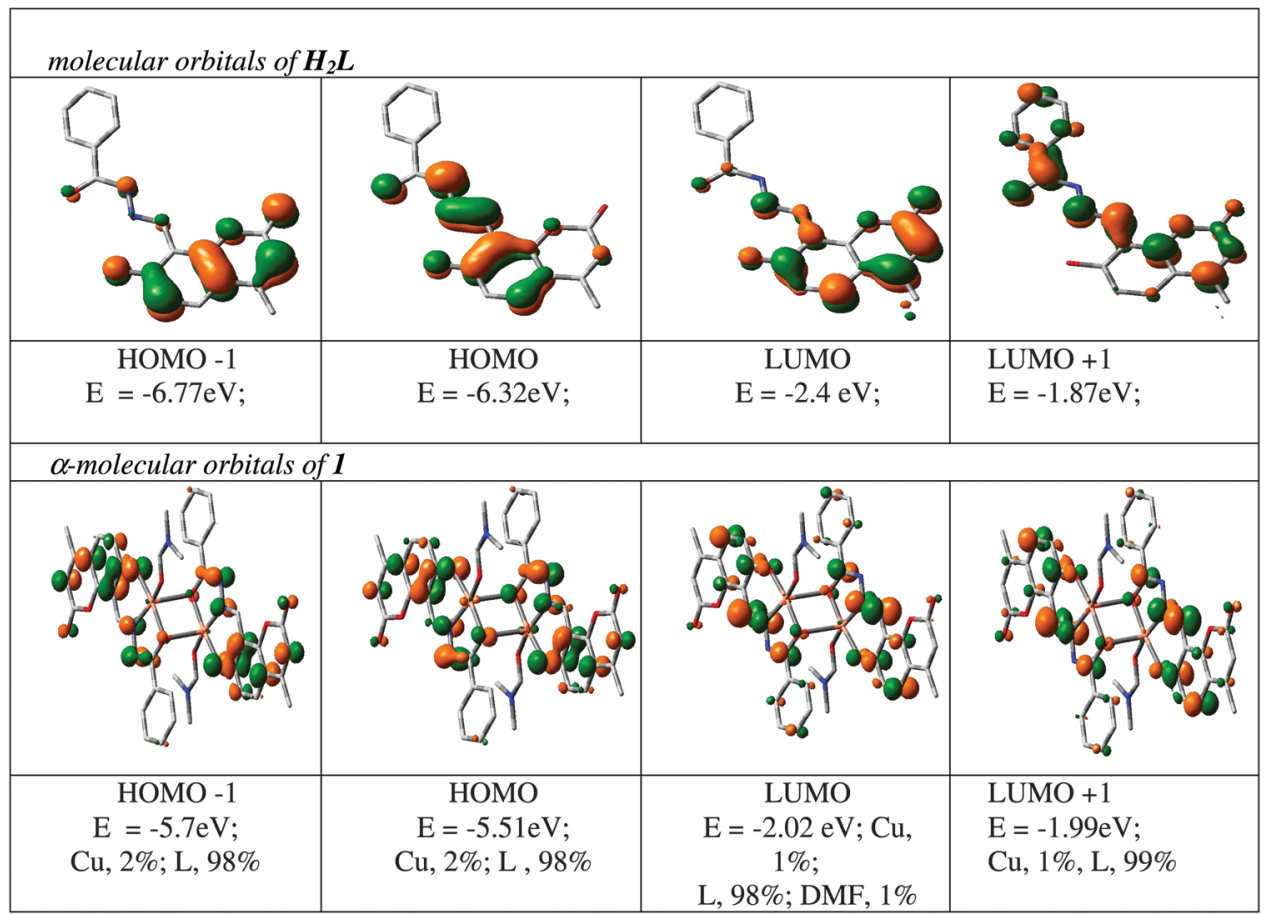

Fig. 3 Contour plots of some selected MOs of $\mathrm{H}_{2} \mathrm{~L}$ and $\mathrm{Cu}_{2}\left[(\mathrm{~L})_{2}(\mathrm{DMF})_{2}\right]$ (1).

both filled and vacant MOs is $>80 \%$ except for LUMO and LUMO+1 where the contribution is: $34 \% \mathrm{~L} ; 62 \% \mathrm{Cu} ; 4 \% \mathrm{DMF}$; and $36 \% \mathrm{~L} ; 60 \% \mathrm{Cu} ; 4 \% \mathrm{DMF}$, respectively. In this case the transition bands inferior to $400 \mathrm{~nm}$ are ILCT in nature except for the HOMO-9 $\rightarrow$ LUMO+1 transition at $360 \mathrm{~nm}(f=0.0201)$ which is a mixture of LMCT and ILCT. Additionally, absorption bands at $434(f=0.0025)$ and $525(f=0.0046) \mathrm{nm}$ are also considered as the mixture of LMCT and ILCT which are due to HOMO-3 $\rightarrow$ LUMO+1 and HOMO $\rightarrow$ LUMO+1 transitions.

\section{Emission spectra}

The emission spectra of $\mathrm{H}_{2} \mathrm{~L}$ and $\mathbf{1}$ were carried out in DMF and methanol, respectively, at room temperature. They show that $\mathrm{H}_{2} \mathrm{~L}$ fluoresces strongly when it's $\pi \rightarrow \pi^{*}$ transition band is excited,

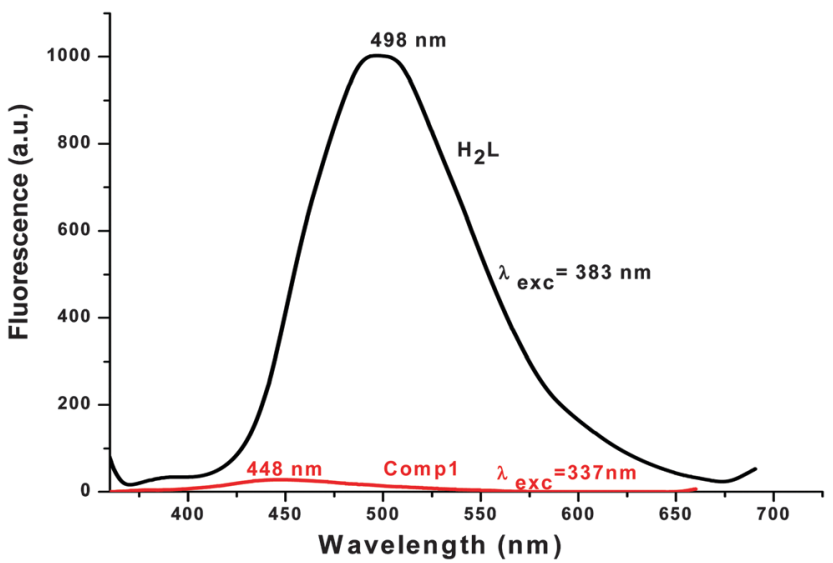

Fig. 4 Emission spectra of $\mathrm{H}_{2} \mathrm{~L}$ (black curve, in DMF) and of the $\mathrm{Cu}\left({ }^{\prime \prime}\right)$ complex (1) (red curve, in $\mathrm{MeOH}$ ). whereas complex 1 is a weak emitter (Fig. 4). For $\mathrm{H}_{2} \mathrm{~L}$, a strong emission band appears at $498 \mathrm{~nm}$ upon excitation at 314, 347 or $383 \mathrm{~nm}$ (which are $\pi \rightarrow \pi^{*}$ bands). This means that $\mathrm{H}_{2} \mathrm{~L}$ shows a high Stokes shift value of $184 \mathrm{~nm}\left(\Delta \lambda^{\prime}=\lambda_{\text {emission }}-\lambda_{\text {absorption }}\right)$ (Fig. 5) which corresponds to the Stokes shift parameter of $11767 \mathrm{~cm}^{-1}$. The Stokes shift parameter indicates the difference in properties and structure between the ground state $S_{0}$ and the first exited state $\mathrm{S} 1,{ }^{56}$ and has been estimated according to the following equation: ${ }^{57}$

$$
\Delta v^{\prime}=v_{\mathrm{abs}}{ }^{\prime}-v_{\mathrm{em}}{ }^{\prime}=\left(1 / \lambda_{\mathrm{abs}}-1 / \lambda_{\mathrm{em}}\right) \times 10^{7} \mathrm{~cm}^{-1}
$$

where: $\lambda_{\mathrm{abs}}$ and $\lambda_{\mathrm{em}}=$ absorbance and emission wavelength $(\mathrm{nm})$, $v_{\text {abs }}{ }^{\prime}$ and $v_{\mathrm{em}}{ }^{\prime}=$ wavenumbers for the absorption and emission maxima $\left(\mathrm{cm}^{-1}\right)$.

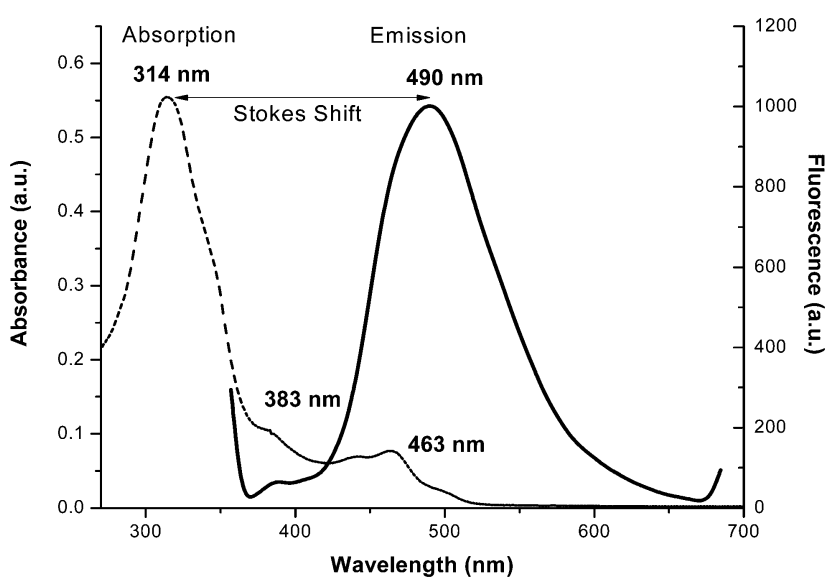

Fig. 5 Emission spectra with the Stokes shift value. 

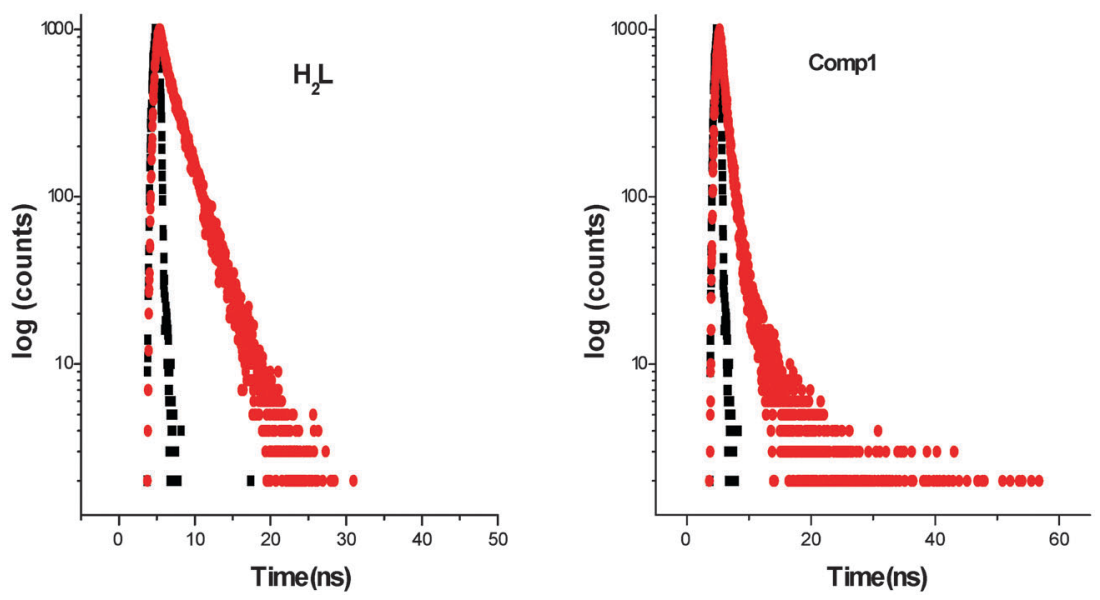

Fig. 6 Exponential decay profile (red) of $\mathrm{H}_{2} \mathrm{~L}$ and complex 1.

Complex 1 fluoresces very weakly at $448 \mathrm{~nm}$ when it is excited at $337 \mathrm{~nm}$. Longer wavelengths of excitation (MLCT/d-d bands) do not produce any emission. Though the Stokes shift parameter of the ligand is comparatively higher with respect to the well-known coumarin dye, coumarin-1 $\left(\mathrm{C} 1 ; 7-\mathrm{NEt}_{2}-4-\mathrm{CH}_{3}\right.$ 1,2-benzopyrone, $\Delta v^{\prime}=4259 \mathrm{~cm}^{-1}$ in acetonitrile), the fluorescence quantum yield of the ligand $\left(\phi_{\mathrm{H} 2 \mathrm{~L}}: 0.17\right)$ is much less than $\mathrm{C} 1\left(\phi_{\mathrm{C} 1}: 0.62\right)$. This is basically due to the presence of an $\mathrm{OH}$ oscillator, which acts as an efficient quencher enhancing the intersystem crossing process. In addition to that, the stretching vibrations of the $\mathrm{CH}, \mathrm{NH}$ and $\mathrm{C}=\mathrm{O}$ oscillators also have an effect on quenching of luminescence.$^{58}$ In the case of 1 , the fluorescence quantum yield $\left(\phi_{1}: 0.008\right)$ decreases by $\sim 20$ times due to the high paramagnetic quenching of the $\mathrm{Cu}(\mathrm{II})$ metal $\left(d^{9}\right) .{ }^{59}$ The decay studies of the free ligand and the complex have been performed in DMF and methanol respectively, upon excitation at $370 \mathrm{~nm}$ (Fig. 6, left). The decay profile of the ligand fits with a mono exponential decay whereas in the case of the complex, the nature of the decay is bi-exponential (Fig. 6, right) The mean lifetime $\left(\tau_{\mathrm{f}}=a_{1} \tau_{1}+a_{2} \tau_{2}\right.$, where $a_{1}$ and $a_{2}$ are relative amplitudes of the decay process for bi-exponential) has been

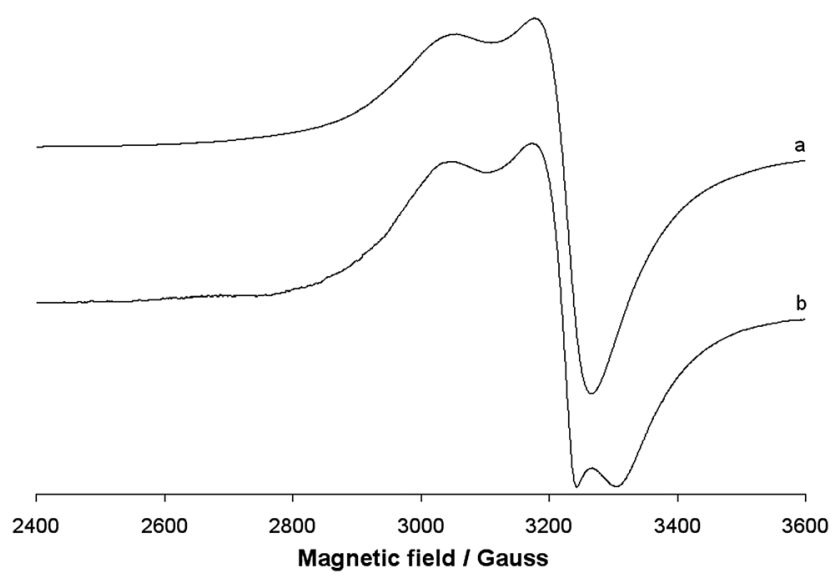

Fig. 7 X-band EPR spectra of the polycrystalline solid complex $\mathbf{1}$ at (a) 298 and (b) $77 \mathrm{~K}$. calculated to compare the excited state stability of the complex ( $1 \mathrm{~ns})$ and the free ligand ( $3 \mathrm{~ns}$ ). This indicates that the excited states of $\mathbf{1}$ are unstable compared to those of $\mathrm{H}_{2} \mathrm{~L}$. Radiative and non-radiative rate constant values have also been calculated showing, as usual, $k_{\mathrm{nr}}$ values $\left[3.09 \times 10^{8}\left(\mathrm{H}_{2} \mathrm{~L}\right)\right.$ and $\left.9.8 \times 10^{8}(\mathbf{1})\right]$ higher than the relative $k_{\mathrm{r}}$ values $\left[6.32 \times 10^{7}\left(\mathrm{H}_{2} \mathrm{~L}\right)\right.$ and $\left.7.97 \times 10^{6}(\mathbf{1})\right]$. In the complex, the rate constant of nonradiative decay is much higher ( $\sim 100$ times $)$ than the radiative decay, evidencing that $\mathbf{1}$ is a very weaker emitter than the ligand.

\section{EPR spectra}

The EPR spectra of the polycrystalline solid complex 1 were recorded at 298 and $77 \mathrm{~K}$. The two spectra are shown in Fig. 7. No resonances below 2800 and above 3400 Gauss and no halffield transition $\Delta M= \pm 2$, attributable to a magnetic coupling between two $3 \mathrm{~d}^{9} \mathrm{Cu}(\mathrm{II})$ ions, were detected. This indicates that the two ions, separated by $3.429 \AA$, are not interacting, in agreement with the EPR behaviour of other $\mathrm{Cu}$ dimeric complexes reported in the literature. ${ }^{60}$ EPR spectra are 'tetragonal' at RT, with two $g$ values, and 'rhombic' at $77 \mathrm{~K}$, with three $g$ values. This suggests a geometric distortion when lowering the temperature, which determines a slight $x, y$ anisotropy. At $\mathrm{RT}$, the order $g_{z} \gg g_{x}=g_{y}>g_{\mathrm{e}}$ (Table 3) is characteristic of a ground state $\Psi$ based on the $\mathrm{Cu}-\mathrm{d}_{x^{2}-y^{2}}$ orbital and it is compatible with the square pyramidal environment of each copper ion. At $77 \mathrm{~K}$, the order $g_{z} \gg g_{y}>g_{y}>g_{\mathrm{e}}$ (Table 3) indicates a ground state $\Psi$ which can be described as a linear combination of Cu- $\mathrm{d}_{x^{2}-y^{2}}$ and Cu- $\mathrm{d}_{z^{2}}$ orbitals, $\Psi=c_{1}\left|\mathrm{~d}_{x^{2}-y^{2}}\right\rangle+c_{2}\left|\mathrm{~d}_{z^{2}}\right\rangle,{ }^{61}$ the parameter $R\left(R=\left(g_{y}-g_{x}\right) /\left(g_{z}-g_{y}\right)\right.$, with $\left.g_{z}>g_{y}>g_{x}\right)$ being indicative of the predominance of the Cu- $\mathrm{d}_{x^{2}-y^{2}}$ orbital $\left(c_{1}>c_{2}\right)$ or $\mathrm{Cu}-\mathrm{d}_{z^{2}} \cdot\left(c_{2}>c_{1}\right) \cdot{ }^{62}$ If $R<1$, the greater contribution to the ground state arises from the Cu- $\mathrm{d}_{z^{2}}$ orbital, while if $R>1$ this arises from Cu- $\mathrm{d}_{x^{2}-y^{2}}$ orbital. ${ }^{61 b}$ For $\mathbf{1}, R$ is 2.7 and this means that $c_{1}>c_{2}$ and that a slight difference between the $x$ and the $y$ axis occurs at low temperatures, but the structure remains close to the square pyramidal geometry. ${ }^{61 b}$ Therefore, variations in temperature cause slight structural changes in bond lengths and angles in the $x y$ plane, which results in a mixing 
Table 3 EPR parameters of complex 1 in the solid state and in some organic solvents ${ }^{a}$

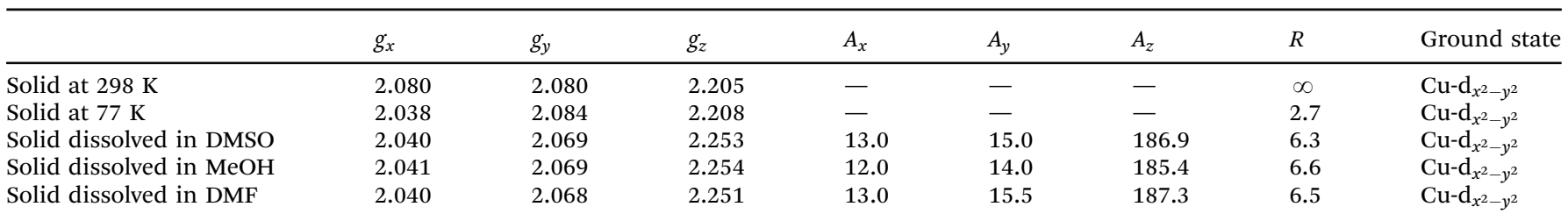

${ }^{a} A_{x}, A_{y}$ and $A_{z}$ values reported in $10^{-4} \mathrm{~cm}^{-1}$.

between the Cu- $\mathrm{d}_{x^{2}-y^{2}}$ and Cu- $\mathrm{d}_{z^{2}}$ orbitals in the singly occupied molecular orbital that bears the unpaired electron. Similar effects induced by the temperature were observed from some other $\mathrm{Cu}(\mathrm{II})$ compounds. ${ }^{63}$ When $\mathbf{1}$ is dissolved in an organic solvent (DMSO, DMF or $\mathrm{MeOH}$ ) at $298 \mathrm{~K}$, the dinuclear $\mathrm{Cu}(\mathrm{II})$ structure is destroyed; the solvent breaks the long $\mathrm{Cu}-\mathrm{O} 4 \#$ bond, replaces the alkoxide oxygen in the axial position and mononuclear $\mathrm{Cu}(\mathrm{II})$ species are formed (Fig. 8). This has been observed for other polynuclear $\mathrm{Cu}(\mathrm{II})$ structures. $^{64}$ In all the three solvents, the spectra are slightly 'rhombic' with $g_{z} \gg g_{y}>g_{y}>g_{\mathrm{e}}$, similarly to what were observed in the solid state (Table 3). Therefore, the ground state is based on the Cu- $\mathrm{d}_{x^{2}-y^{2}}$ orbital and the geometry around copper is a distorted square pyramid. The values of $g_{z}$ and $A_{z}$ are compatible with an equatorial $\mathrm{NO}_{3}$ coordination and a charge close to the neutrality around the metal ion. ${ }^{65}$

Interestingly, in the spectra recorded in $\mathrm{MeOH}$ and DMF, an EPR resonance centered at $g \sim 2.24$ is detected. The intensity of this band increases from $\mathrm{MeOH}$ to DMF and cannot be ascribed to a residual presence of the dimeric structure because no other absorptions (nor at lower and higher magnetic fields) are observed. The broad and unresolved band can be assigned to an aggregation processes originated in $\mathrm{MeOH}$ and DMF, probably favored from the formation of $\pi$ stacking interactions. Owing to such processes, the distance between the $\mathrm{Cu}$ centers decreases significantly and an isotropic band due to the magnetic interaction of the $S=1 / 2$ paramagnetic metal ions appears. These aggregations have been observed for other paramagnetic species

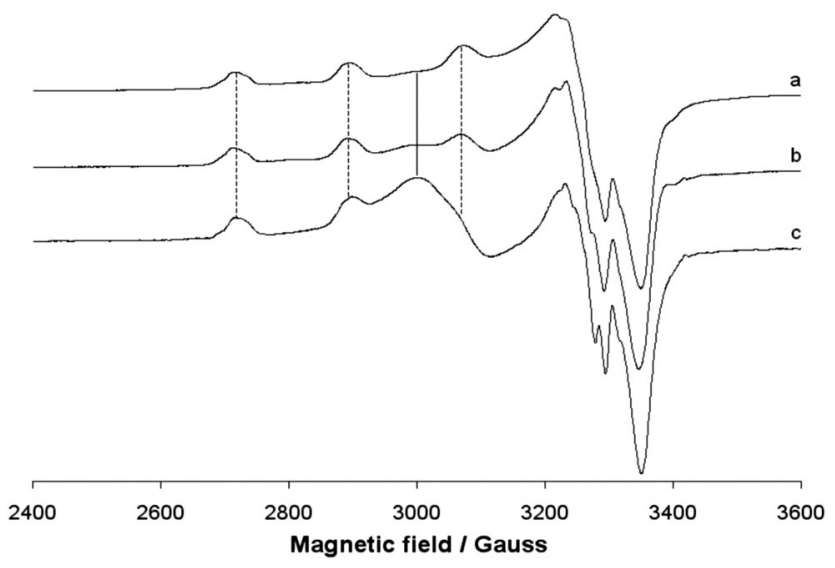

Fig. 8 Anisotropic X-band EPR spectra of the solid complex 1 dissolved in (a) DMSO, (b) MeOH and (c) DMF. The dotted lines indicate the first three parallel resonances due to the coupling between the unpaired electron and the ${ }^{63,65} \mathrm{Cu}$ nucleus, while the full line shows the position of the isotropic band due to the aggregate observed in $\mathrm{MeOH}$ and DMF. and depend on the solvent used; the effect can be detected using EPR spectroscopy but not using UV-vis spectrophotometry. ${ }^{66}$

The appearance of this band, characteristic of the solid samples, is not accompanied by the formation of a precipitate, ruled out by the electronic absorption spectra (Fig. 9). Therefore, this state can be interpreted as the intermediate between the solution and the solid state, in which the molecules undergo aggregation through $\pi$ stacking favored by the presence of the two aromatic rings in the ligand structure.

\section{Magnetic properties}

The variable-temperature magnetic properties (in the temperature range from 5 to $300 \mathrm{~K}$ under an external field of $10000 \mathrm{Oe}$ ) of complex 1 in the form of $\chi_{\mathrm{M}} T v s . T\left(\chi_{\mathrm{M}} v s . T\right.$ inset) plots are illustrated in Fig. $10\left(\chi_{\mathrm{M}}\right.$ is the molar susceptibility for two $\left.\mathrm{Cu}(\mathrm{II})\right)$. At room temperature, the $\chi_{\mathrm{M}} T$ value is $6.74 \mathrm{emu} \mathrm{K} \mathrm{mol}^{-1}$. When lowering the temperature, the $\chi_{\mathrm{M}} T$ value increases smoothly to a maximum value of $8.83 \mathrm{emu} \mathrm{K} \mathrm{mol}^{-1}$ at $30 \mathrm{~K}$. It then decreases sharply and reaches a value of $7.94 \mathrm{emu} \mathrm{K} \mathrm{mol}^{-1}$ at $5 \mathrm{~K}$. The behavior suggests that there is weak ferromagnetic interactions between the bridging dinuclear $\mathrm{Cu}$ (II) ions. Furthermore, the effective magnetic moment at room temperature is 2.07 B.M., which is less than the spin only value of $\mathrm{Cu}$ (II), 2.45 B.M., calculated for two uncoupled spin $1 / 2$ centers.

\section{Antimycobacterial activity}

In the anti-mycobacterial assay, $\mathrm{H}_{2} \mathrm{~L}$ and complex $\mathbf{1}$ were tested against M. tuberculosis H37Rv ATCC 27294 and M. tuberculosis H37Ra ATCC 25177 strains as well as against two clinical strains

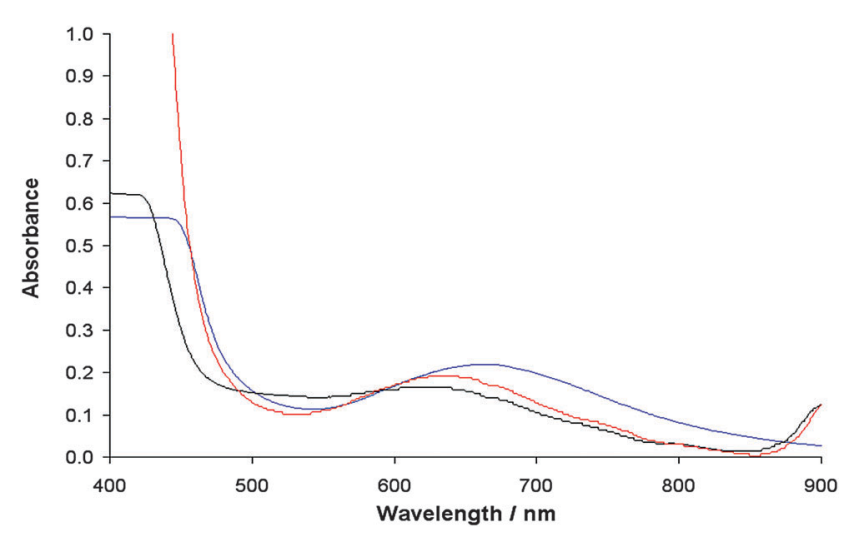

Fig. 9 Electronic absorption spectra of the solid complex 1 dissolved in DMSO (blue), DMF (red) and $\mathrm{MeOH}$ (black). The complex concentration was $1 \times 10^{-3} \mathrm{M}$. 


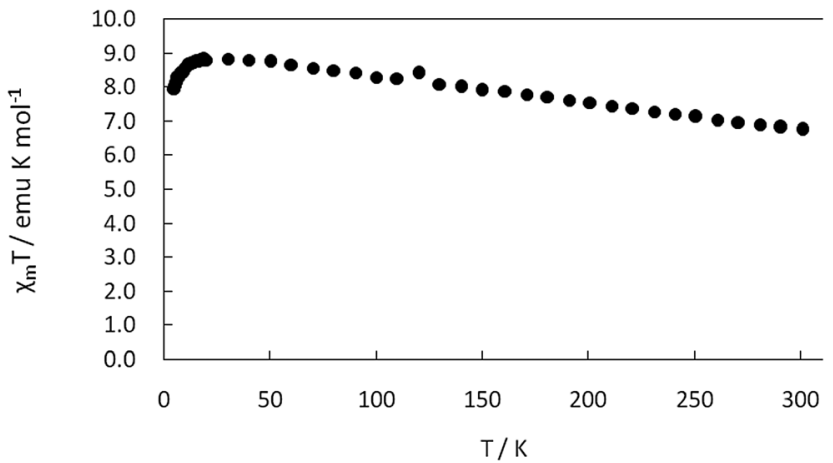

Fig. 10 The $\chi_{M} T$ vs. $T$ plots for complex 1 in the temperature range $5-300 \mathrm{~K}$

(strain 1 and strain 2). The results are shown in Table S4 (ESI $\dagger$ ). M. tuberculosis $\mathrm{H} 37 \mathrm{Rv}$ and M. tuberculosis H37R, well-known indicators, were used for the drug sensitivity tests. ${ }^{20}$ The results showed that the ligand $\mathrm{H}_{2} \mathrm{~L}$ and complex 1 both exhibited antimycobacterial activity against all the tested $M$. tuberculosis strains, with MIC values of $52.96 \mu \mathrm{mol} \mathrm{L}^{-1}$ and MBC values in the range of
52.96-423.68 $\mu \mathrm{mol} \mathrm{L} \mathrm{L}^{-1}$. Both $\mathrm{H}_{2} \mathrm{~L}$ and complex 1 showed the bactericidal activity and killed the bacteria (Table S4 and Fig. S4, ESI $\dagger$ ). Trias et al. ${ }^{67}$ showed that Mycobacterium chelonae developed a pore-forming protein as a mycobacterial porin. In the study of permeability of Mycobacterium smegmatis, Trias and Benz ${ }^{68}$ reported that the mycobacterial porin formed an important hydrophilic structure where small molecules pass through the pores and diffuse into the cell. In this study, we evidence that all compounds showed a considerable efficacy on the Mycobacterial strains. The mycobacterial cell wall includes a large amount of complex lipids, lipopolysaccharides and mycolic acids. This constitution makes the cell wall a hydrophobic strong barrier against antimicrobial agents. ${ }^{69}$ These results are well comparable with previous literature. ${ }^{70}$ The MIC (Minimal Inhibitory Concentration) and MBC (Minimal Bactericidal Concentration) values are higher in the present case. The concerned data respond well while comparing with known drugs like streptomycin and isoniazid.

\section{Cytotoxicity study}

Fig. 11 shows the effects of complex 1 and ligand $\mathrm{H}_{2} \mathrm{~L}$ in human adenocarcinoma cells. In order to determine the cytotoxic effect

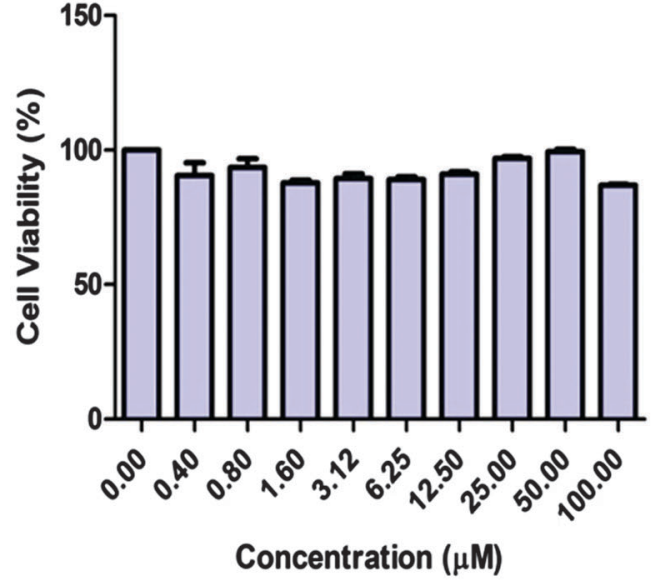

Ligand 24 HRS

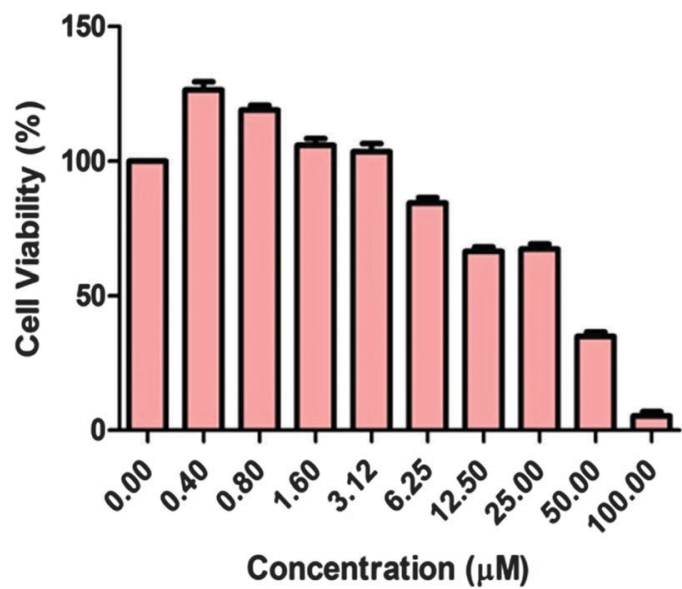

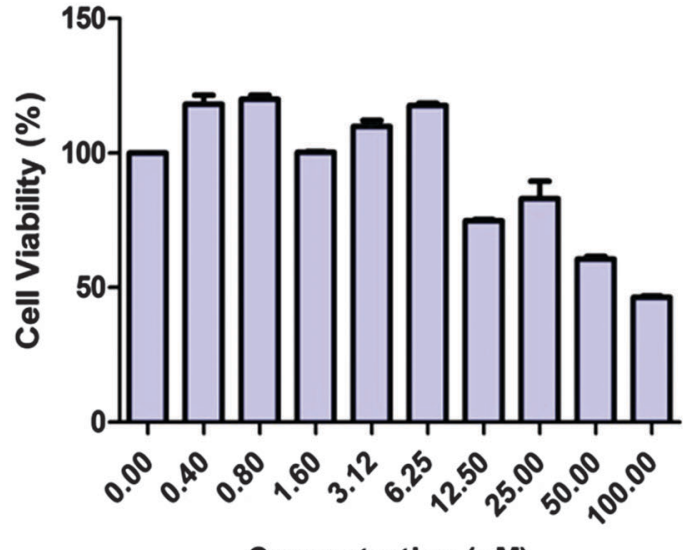

Concentration $(\mu \mathrm{M})$

Ligand 48 HRS

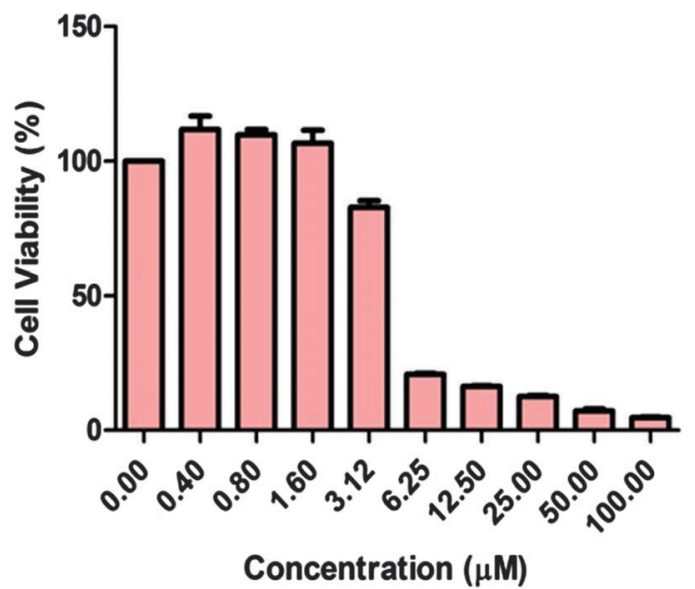

Fig. 11 Evaluation of the cytotoxic effect on the adenocarcinoma cell line. MCF7 cells were seeded $\left(2.5 \times 10^{4}\right.$ cells per $\left.\mathrm{mL}\right)$ and treated with the compounds $(0.4,0.8,1.6,3.12,6.25,12.50,25,50$ and $100 \mu \mathrm{M})$ and cytotoxicity was determined after 24 and 48 hours by MTT assay. 


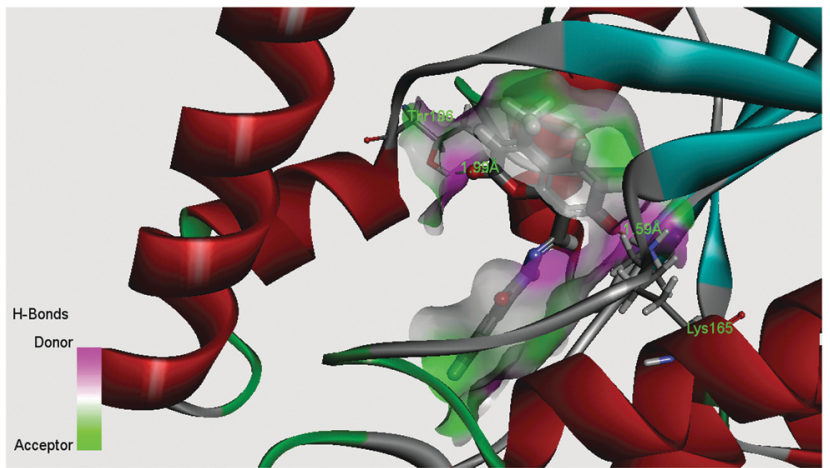

Fig. 12 Surface area (with respect to $\mathrm{H}$-bond donors $\&$ acceptors) of the binding pocket in the best docked pose of the ligand and the protein.

of complex 1 and ligand $\mathrm{H}_{2} \mathrm{~L}$, the adenocarcinoma cells were treated with or without the compounds and the cell viability was tested after 24 and 48 hours by MTT Assay. The results showed that the cell population was significantly decreased after 48 hours of treatment with $\mathrm{H}_{2} \mathrm{~L}$. However complex 1 produced the cytotoxic effect only after 48 hours of incubation. Our results suggest that both complex $\mathbf{1}$ and the ligand are able to induce cytotoxicity in MCF7 cells with an $\mathrm{IC}_{50}$ value of $100 \mu \mathrm{M}$ and $5 \mu \mathrm{M}$. Hence the ligand and complex 1 can have potential anticancer properties.

\section{Docking study}

The enoyl acyl carrier protein reductase (ENR) from $M$. tuberculosis is one of the key enzymes involved in the mycobacterial fatty acid elongation cycle and has been validated as an effective antimicrobial target. In the current study we have docked our ligand inside the binding pocket of enoyl acyl carrier protein reductase of $M$. tuberculosis to get an idea about the mode of action. The crystallographic structure of enoyl acyl carrier protein reductase of $M$. tuberculosis $\mathrm{H}_{3} 7 \mathrm{R}_{\mathrm{v}}$ was downloaded from the RCSB protein data bank (PDB ID: 4U0K), which was resolved at $1.09 \AA$ by X-ray diffraction. Energy minimized structure of the ligand $\left(\mathrm{H}_{2} \mathrm{~L}\right)$ was used for in silico protein ligand docking studies in the cavity of the enzyme. A total of 16 amino acids (Ile21, Gly96, Phe97, Met98, Met103, Met147, Asp148, Phe149, lys165, Ala191, Gly192, Pro193, Ile194, Thr196, and Met199) were present in the cavity sites and involved in the binding process within $3.5 \AA$ radius of the ligand. The ligand, $\mathrm{H}_{2} \mathrm{~L}$, interacts with the protein by ionic interaction with Lys165 (1.59 A, Fig. S5 and S6, ESI $\dagger$ ) and hydrogen bond interaction with Thr196 (1.99 А, Fig. S5 and S6, ESI $\dagger$ ). The relevant data of the docking study are given in Tables S5 and S6 (ESI $\dagger$ ).
The surface area of the active site cavity (with respect to the $\mathrm{H}$ bond donor/acceptor) is depicted in Fig. 12; the carbonyl group and the $-\mathrm{OH}$ group of the coumarin moiety is oriented towards the $\mathrm{H}$-bond donor rich surface of the protein.

\section{Druglikeness and ADMET prediction}

The druglikeness of $\mathrm{H}_{2} \mathrm{~L}$ was checked following Lipinski's rule of five. The ADMET modules of Discovery Studio were used to check the ADMET (absorption, distribution, metabolism, excretion and toxicity) properties of the compounds. Toxicity prediction, aqueous solubility, blood brain barrier penetration, human intestinal absorption, and ames mutagenicity were predicted under the Calculate Molecular Property module of the Small molecule tool of Discovery Studio client 4.0. The predicted data are summarized in Table 4. According to these predictions, the ligand, $\mathrm{H}_{2} \mathrm{~L}$, is well absorbed and non-mutagenic.

\section{Conclusions}

The coumarin-assisted tridentate ligand, [benzoic acid(7-hydroxy4-methyl-2-oxo-2H-chromen-8-ylmethylene)-hydrazide], has been used to synthesize a phenoxo-bridged $\mathrm{Cu}(\mathrm{II})$ dinuclear complex, $\mathrm{Cu}_{2}\left[(\mathrm{~L})_{2}(\mathrm{DMF})_{2}\right](\mathbf{1})$. The solid state structure of $\mathbf{1}$ shows that the $\mathrm{Cu}$ atoms are present in a square-pyramidal arrangement. The variable temperature EPR spectra suggest that a geometrical distortion takes place upon lowering the temperature and that the dinuclear structure is destroyed if the complex is dissolved in coordinating solvents. The temperature dependent magnetic moment supports the presence of weak ferromagnetic interactions between the bridging dinuclear $\mathrm{Cu}(\mathrm{II})$ ions. Both the ligand $\mathrm{H}_{2} \mathrm{~L}$ and complex 1 exhibit anti-mycobacterial activity and considerable efficacy on M. tuberculosis H37Rv ATCC 27294 and M. tuberculosis H37Ra ATCC 25177 strains. Our cytotoxicity study on human adenocarcinoma cells suggests that both complex 1 and the ligand $\mathrm{H}_{2} \mathrm{~L}$ are able to induce cytotoxicity in MCF7 cells. In summary, the studies here discussed have evidenced the activity in the biomedical field of a new copper complex; further investigations in this area with other transition metal ions and chemosensor activities of the ligand for selective detection of metal ions are currently being carried out in our laboratories.

\section{Acknowledgements}

KD and CS would like to thank DST (Department of Science and Technology, New Delhi, India) for the grant (SR/S1/IC-31/2008) to carry out the present study. $\mathrm{AD}$ would like to thank the National Science Council, Taiwan for financial assistance.

Table 4 ADMET prediction of $\mathrm{H}_{2} \mathrm{~L}$

\begin{tabular}{|c|c|c|c|c|c|c|c|c|c|c|}
\hline Compounds & $\begin{array}{l}\text { Molecular } \\
\text { weight }\end{array}$ & $\begin{array}{l}\text { ADMET } \\
\text { solubility } \\
\text { (aqueous) }\end{array}$ & $\begin{array}{l}\text { ADMET } \\
\text { solubility } \\
\text { level }\end{array}$ & $\begin{array}{l}\text { ADMET } \\
\text { absorption } \\
\text { level }^{a}\end{array}$ & $\begin{array}{l}\text { ADMET_A } \\
\log P 98\end{array}$ & $\begin{array}{l}\text { No. of } \\
\text { H-bond } \\
\text { acceptor }\end{array}$ & $\begin{array}{l}\text { No. of } \\
\text { H-bond } \\
\text { donor }\end{array}$ & $\begin{array}{l}\text { Lipniski’s } \\
\text { filter }\end{array}$ & $\begin{array}{l}\text { Druglikeness } \\
\text { inference }\end{array}$ & $\begin{array}{l}\text { Ames } \\
\text { prediction }\end{array}$ \\
\hline $\mathrm{H}_{2} \mathrm{~L}$ & 322.3 & -4.039 & 2 & 0 (good) & 2.957 & 5 & 2 & Yes & Yes, low & Non-mutagen \\
\hline
\end{tabular}

${ }^{a}$ ADMET absorption level: 0, good; 1, moderate; 2, low. 


\section{References}

1 L. Taneja, A. K. Sharma and R. D. Singh, J. Lumin., 1995, 63, 203-214.

2 (a) L. G. Samsonova, R. M. Gadirov, V. V. Ishchenko and O. V. Khilya, Opt. Spectrosc., 2007, 102, 878-884; (b) A. Prakash and B. K. Singh, Int. J. Pure Appl. Chem., 2010, 5, 291-297; (c) A. Prakash, B. K. Singh, N. Bhojak and D. Adhikari, Spectrochim. Acta, Part A, 2010, 76, 356-362.

3 (a) A. Schonberg and N. Latif, J. Am. Chem. Soc., 1954, 76, 6208; (b) A. K. Mitra, S. K. Misra and A. Patra, Synth. Commun., 1980, 10, 915-919; (c) R. N. Gacche and S. G. Jadhav, J. Exp. Clin. Med., 2012, 4, 165-169; (d) H. Zhao, N. Neamati, H. Hong and A. Mazumder, J. Med. Chem., 1997, 40, 242-249.

4 (a) L. A. Singer and N. P. Kong, J. Am. Chem. Soc., 1966, 88, 5213-5219; (b) S. Weigt, N. Huebler, R. Strecker, T. Braunbeck and T. H. Broschard, Reprod. Toxicol., 2012, 33, 133-141.

5 G. Signore, R. Nifosì, L. Albertazzi and R. Bizzarri, J. Biomed. Nanotechnol., 2009, 5, 722-729.

6 (a) J.-M. An, Z.-Y. Yang, M.-H. Yan and T.-R. Li, J. Lumin., 2013, 139, 79-83; (b) Z. Su, K. Chen, Y. Guo, H. Qi, X.-F. Yang and M. Zhao, J. Fluoresc., 2010, 20, 851-856; (c) F. Chen, G. Liu, Y. Shi, P. Xi, J. Cheng, J. Hong, R. Shen, X. Yao, D. Bai and Z. Zeng, Talanta, 2014, 124, 139-145; (d) S. W. Hong, N. J. Jeon, J. Jeong, J. Hong and K. C. Nam, Bull. Korean Chem. Soc., 2013, 34, 1530-1532.

7 (a) G. Verma, A. Marella, M. Shaquiquzzaman, M. Akhtar, M. R. ahmat Ali and M. M. Alam, J. Pharm. BioAllied Sci., 2014, 6, 69-80; (b) E. Macková, K. Hrušková, P. Bendová, A. Vávrová, H. Jansová, P. Hašková, P. Kovaříková, K. Vávrová and T. Šimunek, Chem.-Biol. Interact., 2012, 197, 69-79; (c) L. V. de Freitas, C. C. P. da Silva, J. Ellena, L. Antônio Sodré Costa and N. A. Rey, Spectrochim. Acta, Part A, 2013, 116, 41-48.

8 (a) L. Jin, J. Chen, B. Song, Z. Chen, S. Yang, Q. Li, D. Hu and R. Xu, Bioorg. Med. Chem. Lett., 2006, 16, 5036-5040; (b) A. C. González-Baró, P. Diez, B. S. Parajón-Costa and N. A. Rey, J. Mol. Struct., 2012, 1007, 95-101; (c) P. G. Avaj, C. H. V. Kumar, S. A. Patil, K. N. Shivananda and C. Nagaraju, Eur. J. Med. Chem., 2009, 44, 3552-3559.

9 (a) A. U. Mandakmare and M. L. Navwade, Orient. J. Chem., 1997, 13, 155-158; (b) E. M. Marshall, M. Ryles, K. Butler and L. Weiss, J. Cancer Res. Clin. Oncol., 1994, 120, 535-538.

10 R. D. Thornes, L. Daly and G. Lynch, J. Cancer Res. Clin. Oncol., 1994, 120, S32-S34.

11 (a) S. Roy, T. K. Mondal, P. Mitra, E. L. Torres and C. Sinha, Polyhedron, 2011, 30, 913-922; (b) S. Roy, T. K. Mondal, P. Mitra and C. Sinha, Polyhedron, 2013, 51, 27-40.

12 (a) M. Zhao, C. Stern, A. G. M. Barrett and B. M. Hoffman, Angew. Chem., Int. Ed., 2003, 42, 462-464; (b) H. Zheng, W. Zhe-Ming, G. Song and Y. Chun-Hua, Inorg. Chem., 2006, 45, 6694-6705; (c) J. S. Miller, Dalton Trans., 2006, 2742-2749; (d) C. Cadiou, M. Murrie, C. Paulsen, V. Villar, W. Wernsdorfer and R. E. P. Winpenny, Chem. Commun., 2001, 2666-2667.
13 (a) P. Molenveld, J. F. J. Engbersen and D. N. Reinhoudt, Chem. Soc. Rev., 2000, 29, 75-86; (b) T. Niittymaki and H. Lonnberg, Org. Biomol. Chem., 2006, 4, 15-25; (c) Q.-X. Xiang, J. Zhang, P.-Y. Liu, C.-Q. Xia, Z.-Y. Zhou, R.-G. Xie and X.-Q. Yu, J. Inorg. Biochem., 2005, 99, 1661-1669.

14 (a) D. Mastropaolo, D. A. Powers, J. A. Potenza and H. J. Schugar, Inorg. Chem., 1976, 15, 1444-1451; (b) A. Drzewiecka, A. E. Koziol, M. Lowczak and T. Lis, Acta Crystallogr., Sect. E: Struct. Rep. Online, 2007, 63, m2339; (c) G. Zhang, G. Yang and J. S. Ma, Cryst. Growth Des., 2006, 6, 375-381.

15 Bioinorganic Chemistry, ed. I. Bertini, H. B. Gray, S. J. Lippard and J. S. Valentine, University Science Books, Mill Valley, CA, 1994.

16 Magneto-Structural Correlation in Exchange-Coupled Systems, ed. R. D. Willett, D. Gatteschi and O. Kahn, NATO AS1 Series C, 140, D. Reidel Publishing Co, Dordrecht, The Netherlands, 1985.

17 D. J. Hodgson, Prog. Inorg. Chem., 1975, 19, 173-178.

18 A. L. Okunade and M. P. F. Elvin-Lewis, Phytochemistry, 2004, 65, 1017-1022.

19 N. Lall, M. D. Sarma, B. Hazra and J. J. Meyer, J. Antimicrob. Chemother., 2003, 51, 435-438.

20 (a) E. Banfi, M. G. Mamolo, D. Zampieri, L. Vio and C. M. Bragadin, J. Antimicrob. Chemother., 2001, 48, 705-711; (b) V. Jarlier and H. Nikaido, FEMS Microbiol. Lett., 1994, 123, 11-18.

21 K. H. K. Naik, S. Selvaraj and N. Naik, Spectrochim. Acta, Part A, 2014, 131, 599-605.

22 D. F. Eaten, Pure Appl. Chem., 1988, 60, 1107-1114.

23 S. R. Stoyanov, J. M. Villegas and D. P. Rillema, Inorg. Chem., 2002, 41, 2941-2945.

24 WINEPR SimFonia, version 1.25 aass, Bruker Analytische Messtechnik GmbH, Karlsruhe, 1996.

25 G. B. Bagihalli, P. G. Avaji, S. A. Patil and P. S. Badam, Eur. J. Med. Chem., 2008, 43, 2639-2649.

26 (a) SADABS Bruker AXS, Madison, Wisconsin, USA, 2004; SAINT, Software Users Guide, Version 6.0; Bruker Analytical X-ray Systems, Madison, WI, 1999; (b) G. M. Sheldrick, SADABS v2.03: Area-Detector Absorption Correction, University of Göttingen, Germany, 1999.

27 A. Altomare, M. C. Burla, M. Camalli, G. L. Cascarano, C. Giacovazzo, A. Guagliardi, A. G. G. Moliterni, G. Polidori and R. Spagna, J. Appl. Crystallogr., 1999, 32, 115-119.

28 G. M. Sheldrick, Acta Crystallogr., Sect. A: Found. Crystallogr., 2008, 64, 112-122.

29 L. J. Farrugia, J. Appl. Crystallogr., 1999, 32, 837-838.

30 C. Lee, W. Yang and R. G. Parr, Phys. Rev. B: Condens. Matter Mater. Phys., 1988, 37, 785-789.

31 M. J. Frisch, G. W. Trucks, H. B. Schlegel, G. E. Scuseria, M. A. Robb, J. R. Cheeseman, J. A. Montgomery Jr, T. Vreven, K. N. Kudin, J. C. Burant, J. M. Millam, S. S. Iyengar, J. Tomasi, V. Barone, B. Mennucci, M. Cossi, G. Scalmani, N. Rega, G. A. Petersson, H. Nakatsuji, M. Hada, M. Ehara, K. Toyota, R. Fukuda, J. Hasegawa, M. Ishida, T. Nakajima, Y. Honda, O. Kitao, H. Nakai, M. Klene, X. Li, J. E. Knox, H. P. Hratchian, J. B. Cross, V. Bakken, C. Adamo, J. Jaramillo, R. Gomperts, 
R. E. Stratmann, O. Yazyev, A. J. Austin, R. Cammi, C. Pomelli, J. W. Ochterski, P. Y. Ayala, K. Morokuma, G. A. Voth, P. Salvador, J. J. Dannenberg, V. G. Zakrzewski, S. Dapprich, A. D. Daniels, M. C. Strain, O. Farkas, D. K. Malick, A. D. Rabuck, K. Raghavachari, J. B. Foresman, J. V. Ortiz, Q. Cui, A. G. Baboul, S. Clifford, J. Cioslowski, B. B. Stefanov, G. Liu, A. Liashenko, P. Piskorz, I. Komaromi, R. L. Martin, D. J. Fox, T. Keith, M. A. Al-Laham, C. Y. Peng, A. Nanayakkara, M. Challacombe, P. M. W. Gill, B. Johnson, W. Chen, M. W. Wong, C. Gonzalez and J. A. Pople, GAUSSIAN 03 Revision D 01, Gaussian Inc., Wallingford, CT, 2004.

32 GaussView3.0, Gaussian, Pittsburgh, PA.

33 P. J. Hay and W. R. Wadt, J. Chem. Phys., 1985, 82, 270-283.

34 R. Bauernschmitt and R. Ahlrichs, Chem. Phys. Lett., 1996, 256, 454-464.

35 M. K. Casida, C. Jamorski, K. C. Casida and D. R. Salahub, J. Chem. Phys., 1998, 108, 4439-4449.

36 R. E. Stratmann, G. E. Scuseria and M. J. Frisch, J. Chem. Phys., 1998, 109, 8218-8224.

37 M. Cossi, N. Rega, G. Scalmani and V. Barone, Comput. Chem., 2003, 24, 669-681.

38 N. M. O'Boyle, A. L. Tenderholt and K. M. Langner, J. Comput. Chem., 2008, 29, 839-845.

39 B. D. Becton, Dickinson and Company Newsletter BD Bactec MGIT 960 SIRE kit now FDA-cleared for susceptibility testing of Mycobacterium tuberculosis, Microbiology News \& Ideas, 2002, 13, 4.

40 NCCLS, (2003). National Committee for Clinical Laboratory Standards (NCCLS). Susceptibility Testing of Mycobacteria, Nocardiae, and Other Aerobic Actinomycetes; Approved Standard. NCCLS document M24-A [ISBN 1-56238-500-3]. NCCLS, 940 West Valley Road, Suite 1400, Wayne, Pennsylvania 19087-1898 USA, 2003.

41 L. Collins and S. G. Franzblau, Antimicrob. Agents Chemother., 1997, 41, 1004-1009.

42 A. Jimenez-Arellanes, M. Meckes, R. Ramirez, J. Torres and J. Luna-Herrera, Phytother. Res., 2003, 17, 903-908.

43 (a) G. R. Battu and B. M. Kumar, Pharmacogn. J., 2010, 2, 456-463; (b) P. Bontempo, V. Carafa, R. Grassi, A. Basile, G. C. Tenore, C. Formisano, D. Rigano and L. Altucci, Food Chem. Toxicol., 2013, 304-312.

44 T. Mosman, J. Immunol. Methods, 1983, 65, 55-63.

45 C. A. Lipinski, F. Lombardo, B. W. Dominy and P. J. Feeney, Adv. Drug Delivery Rev., 2001, 46, 3-26.

46 C. A. Lipinski, Drug Discovery Today: Technol., 2004, 1, 337-341.

47 Discovery Studio 4.0 is a product of Accelrys Inc, San Diego, CA, USA.

48 K. Nakamoto, Infrared and Raman Spectra of Inorganic and Coordination Compounds, Parts A and B, John Wiley, New York, 5th edn, 1997.

49 A. W. Addison, T. N. Rao, J. Reedijk, J. van Rijn and G. C. Verschoor, J. Chem. Soc., Dalton Trans., 1984, 1349-1356.

50 (a) M. Sakamoto, S. Itose, T. Ishimori, N. Matsumoto, H. Ōkawa and S. Kida, Dalton Trans., 1989, 2083-2088; (b) Y. Shiping, C. Peng, L. Daizheng, J. Zonghui, W. Genglin, W. Honggen and Y. Xinkan, Polyhedron, 1992, 11, 879-883; (c) P. Cheng, D. Liao, S. Yan, J. Cui, Z. Jiang, G. Wang, X. Yao and H. Wang, Helv. Chim. Acta, 1997, 80, 213-219; (d) K. Bertoncello, G. D. Fallon, J. H. Hodgkin and K. S. Murray, Inorg. Chem., 1988, 27, 4750-4758.

51 R. Gupta, S. Mukherjee and R. Mukherjee, J. Chem. Soc., Dalton Trans., 1999, 4025-4030.

52 Y. Shiping, C. Peng, L. Daizheng, J. Zonghui, W. Genglin, W. Honggen and Y. Xinkan, Polyhedron, 1992, 11, 879-883. 53 (a) S. Torelli, C. Belle, I. Gautier-Luneau, J. L. Pierre, E. Saint-Aman, J. M. Latour, L. Le Pape and D. Luneau, Inorg. Chem., 2000, 39, 3526-3536; (b) S. K. Dutta, U. Florke, S. Mohanta and K. Nag, Inorg. Chem., 1998, 37, 5029-5032.

54 A. B. P. Lever, Inorganic Electronic Spectroscopy, 2nd edn, Elsevier, New York, 1984.

55 U. Ray, K. K. Sarker, G. Mostafa, T.-H. Lu, M. S. El Fallah and C. Sinha, Polyhedron, 2006, 25, 2764-2772.

56 M. S. Refat, Spectrochim. Acta, Part A, 2007, 68, 1393-1405. 57 A. E. H. Machado, D. Severino, J. Ribeiro, R. De Paula, M. H. Gehlen, H. P. M. de Oliveira, M. D. S. Matos and J. A. de Miranda, Photochem. Photobiol. Sci., 2004, 3, 79-86.

58 (a) J. L. Kropp and M. W. Windsor, J. Chem. Phys., 1963, 39, 2769-2770; (b) J. L. Kropp and M. W. Windsor, J. Chem. Phys., 1965, 42, 1599-1608.

59 J. H. Chang, Y. M. Choi and Y.-K. Shin, Bull. Korean Chem. Soc., 2001, 22, 527-533.

60 S. Thakurta, P. Roy, G. Rosair, C. J. Gómez-García, E. Garribba and S. Mitra, Polyhedron, 2009, 28, 695-702.

61 (a) B. J. Hathaway and D. E. Billing, Coord. Chem. Rev., 1970, 5, 143-207; (b) E. Garribba and G. Micera, J. Chem. Educ., 2006, 83, 1229-1235.

62 R. J. Fereday, P. Hodgson, S. Tyagi and B. J. Hathaway, J. Chem. Soc., Dalton Trans., 1981, 2070-2077.

63 M. A. Halcrow, Chem. Soc. Rev., 2013, 42, 1784-1795.

64 (a) J. C. Jeffery, J. P. Maher, C. A. Otter, P. Thornton and M. D. Ward, J. Chem. Soc., Dalton Trans., 1995, 819-824; (b) G. van Albada, I. Mutikainen, W. J. J. Smeets, A. L. Spek, U. Turpeinen and J. Reedijk, Inorg. Chim. Acta, 2002, 327, 134-139; (c) W. A. Alves, R. H. de Almeida Santos, A. Paduan-Filho, C. C. Becerra, A. C. Borin and A. M. Da Costa Ferriera, Inorg. Chim. Acta, 2004, 357, 2269-2278; (d) M. A. Ali, A. H. Mirza, R. J. Fereday, R. J. Butcher, J. M. Fuller, S. C. Drew, L. R. Gahan, G. R. Hanson, B. Moubaraki and K. S. Murray, Inorg. Chim. Acta, 2005, 358, 3937-3948; (e) I. A. Koval, M. Sgobba, M. Huisman, M. Lüken, E. Saint-Aman, P. Gamez, B. Krebs and J. Reedijk, Inorg. Chim. Acta, 2006, 359, 4071-4078.

65 J. Peisach and W. E. Blumberg, Arch. Biochem. Biophys., 1974, 165, 691-708.

66 A. Stasko, V. Brezova, S. Biskupic and V. Misik, Free Radical Res., 2007, 41, 379-383.

67 J. Trias, V. Jarlier and R. Benz, Science, 1992, 258, 1479-1481.

68 J. Trias and R. Benz, Mol. Microbiol., 1994, 14, 283-286. 
69 (a) D. E. Minnikin and M. Goodfellow, in Microbiological classification and identification, ed. R. G. Board, Academic, London, 1980, p. 189; (b) D. E. Minnikin, Lipids, complex lipids, their chemistry, biosynthesis and roles, in The biology of mycobacteria, ed. C. Ratledge and J. Stanford, Academic Press, Inc, London, 1982, p. 95.
70 (a) K. Das, S. Nandi, S. Mondal, T. Askun, Z. Canturk, P. Celikboyun, C. Massera, E. Garribba, A. Datta, C. Sinha and T. Akitsu, New J. Chem. 2015, 39, 1101-1114; (b) K. Das, A. Datta, S. Nandi, S. B. Mane, S. Mondal, C. Massera, C. Sinha, C.-H. Hung, T. Askun, P. Celikboyun, Z. Cantürk, E. Garribba and T. Akitsu, Inorg. Chem. Front., 2015, DOI: 10.1039/C5QI00060B. 